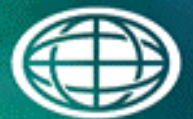

Savannah River

National Laboratory ${ }^{m}$

OPERATEO BY SAVANMAH RIVER NUCLEAR SOLUTIONS

SRS Sludge Batch Qualification and

Processing: Historical Perspective and

Lessons Learned

\author{
M.J. Cercy \\ D.K. Peeler \\ M.E. Stone
}

September 2013

SRNL-STI-2013-00585 


\section{DISCLAIMER}

This work was prepared under an agreement with and funded by the U.S. Government. Neither the U.S. Government or its employees, nor any of its contractors, subcontractors or their employees, makes any express or implied:

1. warranty or assumes any legal liability for the accuracy, completeness, or for the use or results of such use of any information, product, or process disclosed; or

2. representation that such use or results of such use would not infringe privately owned rights; or

3. endorsement or recommendation of any specifically identified commercial product, process, or service.

Any views and opinions of authors expressed in this work do not necessarily state or reflect those of the United States Government, or its contractors, or subcontractors.

\section{Printed in the United States of America \\ Prepared for U.S. Department of Energy}


Keywords:

DWPF Glass Product Control Program Waste Form Qualification

Waste Acceptance

Retention: Permanent

\title{
SRS Sludge Batch Qualification and Processing: Historical Perspective and Lessons Learned
}

\author{
M.J. Cercy \\ D.K. Peeler \\ M.E. Stone
}

September 2013

Prepared for the U.S. Department of Energy under contract number DE-AC09-08SR22470.

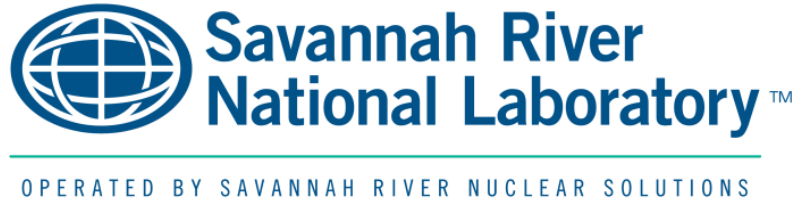




\section{REVIEWS AND APPROVALS}

\section{AUTHORS:}

M.J. Cercy, E\&CPT Research Programs Date

D.K. Peeler, E\&CPT Research Programs

Date

M.E. Stone, E\&CPT Research Programs

Date

TECHNICAL REVIEW:

S.H. Reboul, E\&CPT Research Programs

Date

APPROVAL:

C.C. Herman, E\&CPT Hanford Program Manager

Date

S.L. Marra, Manager

Date

Environmental \& Chemical Process Technology Research Programs 


\section{TABLE OF CONTENTS}

LIST OF TABLES vii

LIST OF FIGURES vii

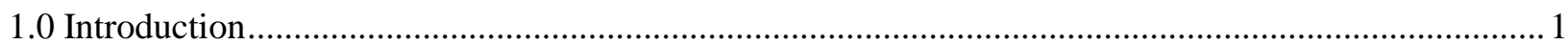

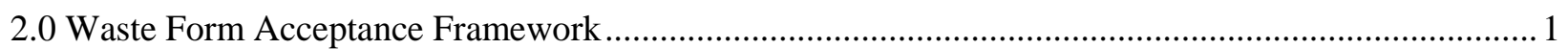

3.0 DWPF HLW Glass Product Control Program and Waste Feed Acceptance Overview ......................... 4

3.1 Elements of the Glass Product Control Program.......................................................................... 4

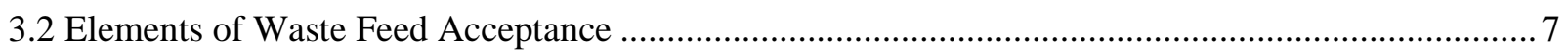

3.3 Sampling to Support Glass Product Control Program and Feed Acceptance..................................... 8

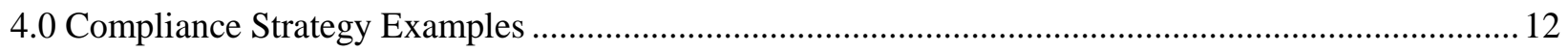

5.0 Overview of DWPF Startup Program and Qualification Runs ........................................................ 16

6.0 Facility or Operational Changes Impacting Sludge Batch Qualification.......................................... 19

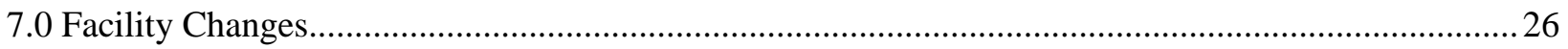

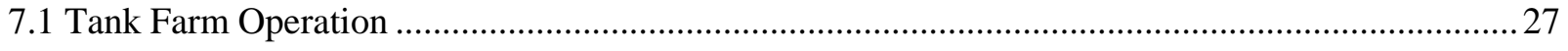

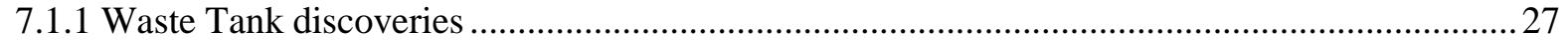

7.1.2 Mixing Pump Degradation and Failures................................................................................. 27

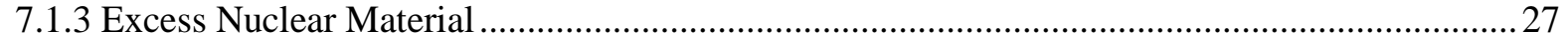

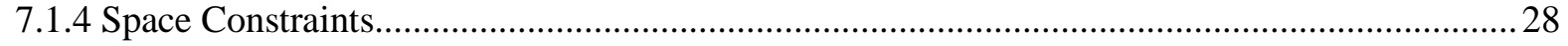

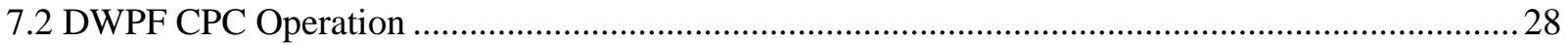

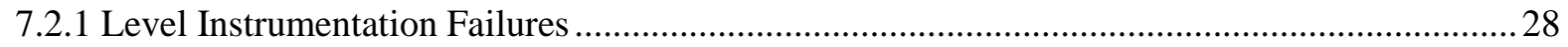

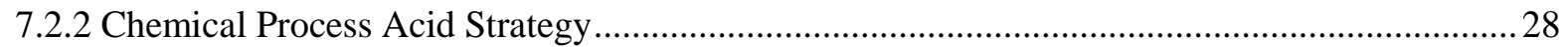

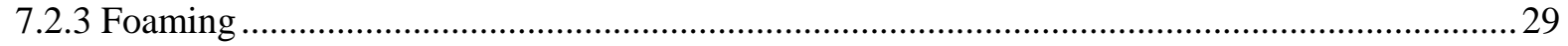

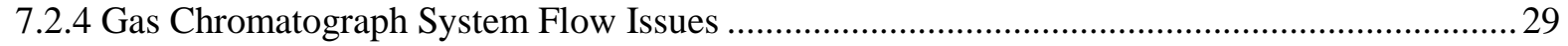

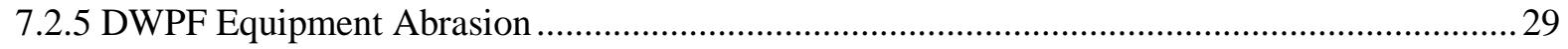

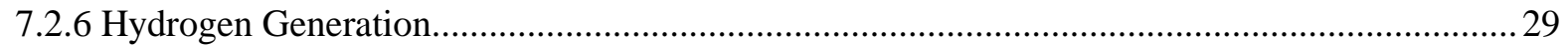

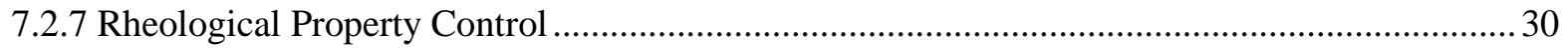

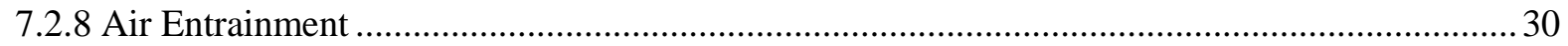

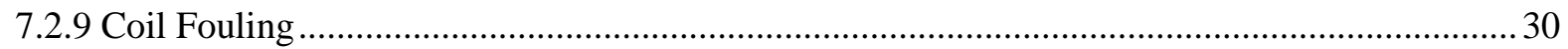

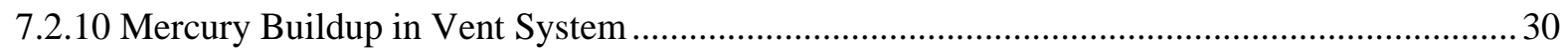

7.2.11 Melter Offgas Flammability Constraints ................................................................................ 31

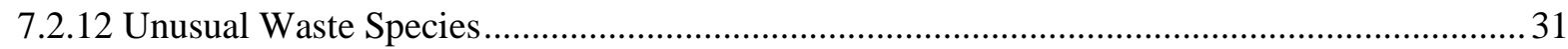

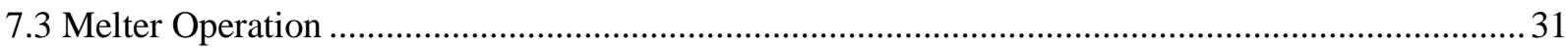

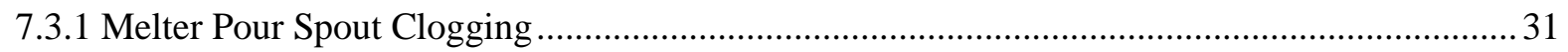


7.3.2 Increased Waste Loading Target and Glass Model Improvements ......................................... 31

7.3.3 Implementation of Forced Convection in the Melter............................................................. 32

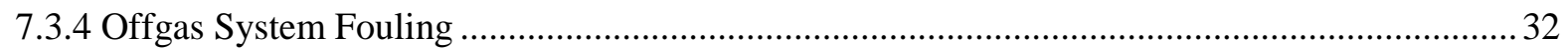

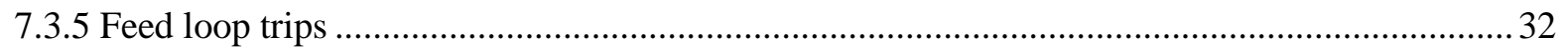

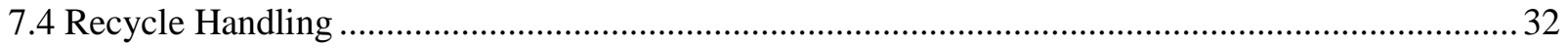

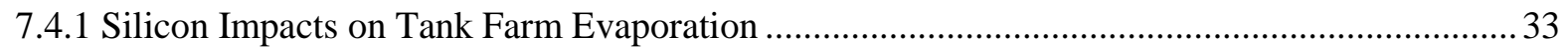

7.4.2 Tank Farm Space Constraints / Recycle Reduction Efforts...................................................... 33

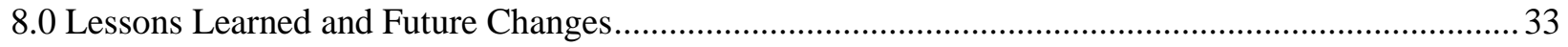

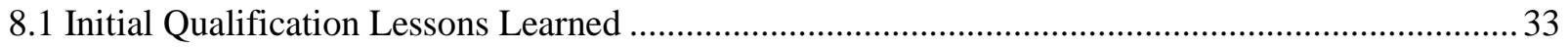

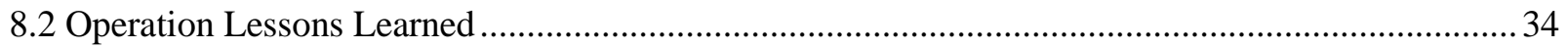

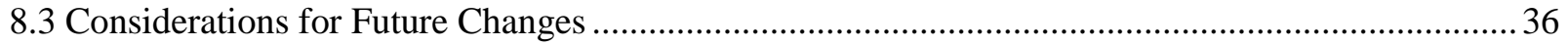

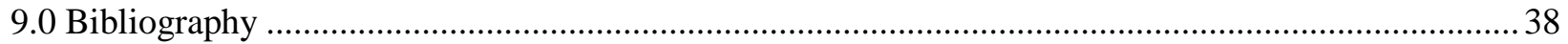

Appendix A . EM-WAPS Crosswalk to WCP/WQR (WSRC-IM-91-116-X)...........................................

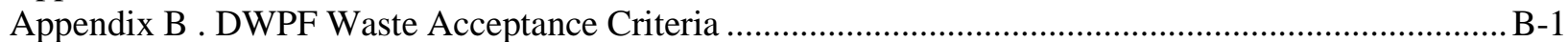

Appendix C . Sludge Batch Preparation and Qualification Flowchart ................................................... 


\section{LIST OF TABLES}

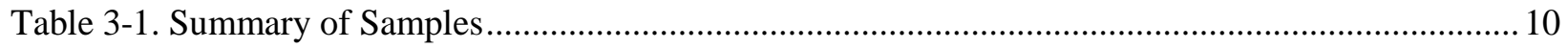

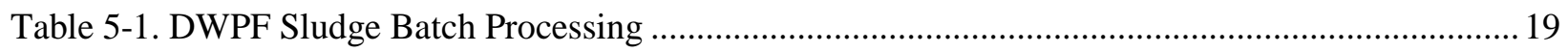

Table A-1. EM-WAPS Crosswalk to WCP/WQR (WSRC-IM-91-116-X) ............................................. A-2

Table B-1. DWPF Waste Acceptance Criteria.................................................................................. B-2

\section{LIST OF FIGURES}

Figure 2-1. Waste Form Requirements and Compliance Documents ....................................................... 2

Figure 2-2. Canistered Waste Form Production Records....................................................................... 3

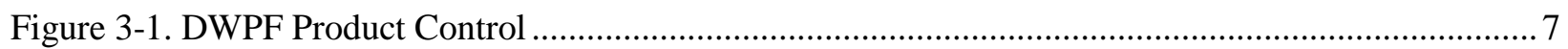

Figure 3-2. Simplified SRS Liquid Waste System Interfaces ................................................................ 8

Figure 3-3. Sampling Overview Process Diagram................................................................................ 9

Figure 4-1. Tasks Planned to Satisfy EM-WAPS Specification 1.1.1, Chemical Composition Projections

Figure 4-2. Strategies to Determine Chemical Composition During Production (EM-WAPS Specification 1.1.2) 15

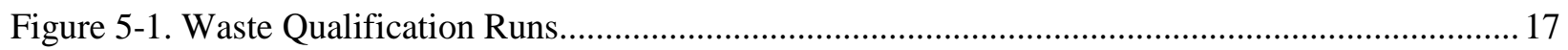

Figure C-1 Sludge Batch Preparation and Qualification Flowchart ...................................................... C-2 


\section{LIST OF ABBREVIATIONS}

\begin{tabular}{|c|c|}
\hline ARP & Actinide Removal Process \\
\hline $\mathrm{CPC}$ & Chemical Process Cell \\
\hline DOE & Department of Energy \\
\hline DSS & Decontaminated Salt Solution \\
\hline DWPF & Defense Waste Processing Facility \\
\hline EA & Environmental Assessment \\
\hline EM & Environmental Management \\
\hline EM-WAPS & DOE-EM Waste Acceptance Product Specifications \\
\hline ESP & Extended Sludge Processing \\
\hline GPCP & Glass Product Control Program \\
\hline GWSB & Glass Waste Storage Building \\
\hline HLW & High Level Waste \\
\hline $\mathrm{HM}$ & H-Modified PUREX Process \\
\hline HQ & Headquarters \\
\hline IAEA & International Atomic Energy Agency \\
\hline LFL & Lower Flammability Limit \\
\hline MCU & Modular Caustic Side Solvent Extraction Unit \\
\hline MFT & Melter Feed Tank \\
\hline MST & Monosodium Titanate \\
\hline PCCS & Product Composition Control System \\
\hline PCT & Product Consistency Test \\
\hline PHA & Precipitate Hydrolysis Aqueous \\
\hline PUREX & Plutonium/Uranium Extraction \\
\hline $\mathrm{R} \& \mathrm{D}$ & Research and Development \\
\hline SB & Sludge Batch \\
\hline SCIX & Small Column Ion Exchange \\
\hline SME & Slurry Mix Evaporator \\
\hline SR & Savannah River \\
\hline SRAT & Sludge Receipt and Adjustment Tank \\
\hline SRNL & Savannah River National Laboratory \\
\hline SRR & Savannah River Remediation \\
\hline SRS & Savannah River Site \\
\hline SWPF & Salt Waste Processing Facility \\
\hline $\mathrm{T}_{\mathrm{L}}$ & Liquidus temperature \\
\hline
\end{tabular}




$\begin{array}{ll}\text { TCLP } & \text { Toxicity Characteristic Leaching Procedure } \\ \text { WAC } & \text { Waste Acceptance Criteria } \\ \text { WA-SRD } & \text { Waste Acceptance System Requirements Document } \\ \text { WCP } & \text { Waste Form Compliance Plan } \\ \text { WCS } & \text { Waste Characterization System } \\ \text { WL } & \text { Waste Loading } \\ \text { WQR } & \text { Waste Form Qualification Reports } \\ \text { wt\% } & \text { Weight Percent } \\ \text { WTP } & \text { Waste Treatment and Immobilization Plant } \\ \eta & \text { Viscosity }\end{array}$


SRNL-STI-2013-00585

Revision 0

This page intentionally left blank 


\subsection{Introduction}

The Savannah River Site (SRS) began the process to investigate and then qualify a glass waste form and process for the disposition of high level waste (HLW) glass in the 1970s. These efforts resulted in the startup of radioactive operations of the SRS Defense Waste Processing Facility (DWPF) in March 1996. Before startup of the DWPF, a number of programs were put in place (with significant research, development, and testing supporting the programs) to demonstrate that DWPF would consistently produce a waste form that would meet the Department of Energy's (DOE) Environmental Management Waste Acceptance Product Specifications (EM-WAPS) for vitrified high level waste forms.

SRS organizations have issued several reports and briefing packages that address the rationale, experience, and lessons learned during startup, initial operations, and continued operations of the facility. Information from these experiences relative to the qualification of waste feed and the HLW glass waste form is of interest to the Hanford organizations as they develop their waste feed acceptance and product qualification programs.

This report provides a historical overview and lessons learned associated with the SRS sludge batch (SB) qualification and processing programs. The report covers the framework of the requirements for waste form acceptance, the DWPF Glass Product Control Program (GPCP), waste feed acceptance, examples of how the program complies with the specifications, an overview of the Startup Program, and a summary of continuous improvements and lessons learned. The report includes a bibliography of previous reports and briefings on the topic.

\subsection{Waste Form Acceptance Framework}

DOE began evaluating waste forms for HLW late in the 1970's. After significant research and development was performed on the potential waste form and the associated technologies for its production, a Record of Decision was issued in December 1982 selecting borosilicate glass as the waste form. Also the Nuclear Waste Policy Act of 1982 mandated that HLW be sent to a federal repository. President Reagan ratified the DOE decision to send defense HLW to a civilian repository in 1985.

Early in the 1990's, the Waste Acceptance System Requirements Document (WA-SRD) [44] was generated by the Office of Civilian Radioactive Waste Management requiring the DOE Office of Environmental Management to develop the Waste Acceptance Product Specifications for Vitrified High-Level Waste Forms. [42] The waste form producer must then provide a Waste Form Compliance Plan (WCP) to describe the strategies that will be used to comply with the EMWAPS. The Waste Form Qualification Report provides the technical bases to demonstrate the ability of the waste form producer to comply with the EM-WAPS. The Production Records and Storage and Shipping Records provide evidence that an acceptable waste form was produced. Figure 2-1 shows the relationship between these documents and other documents generated by the waste form producer. 


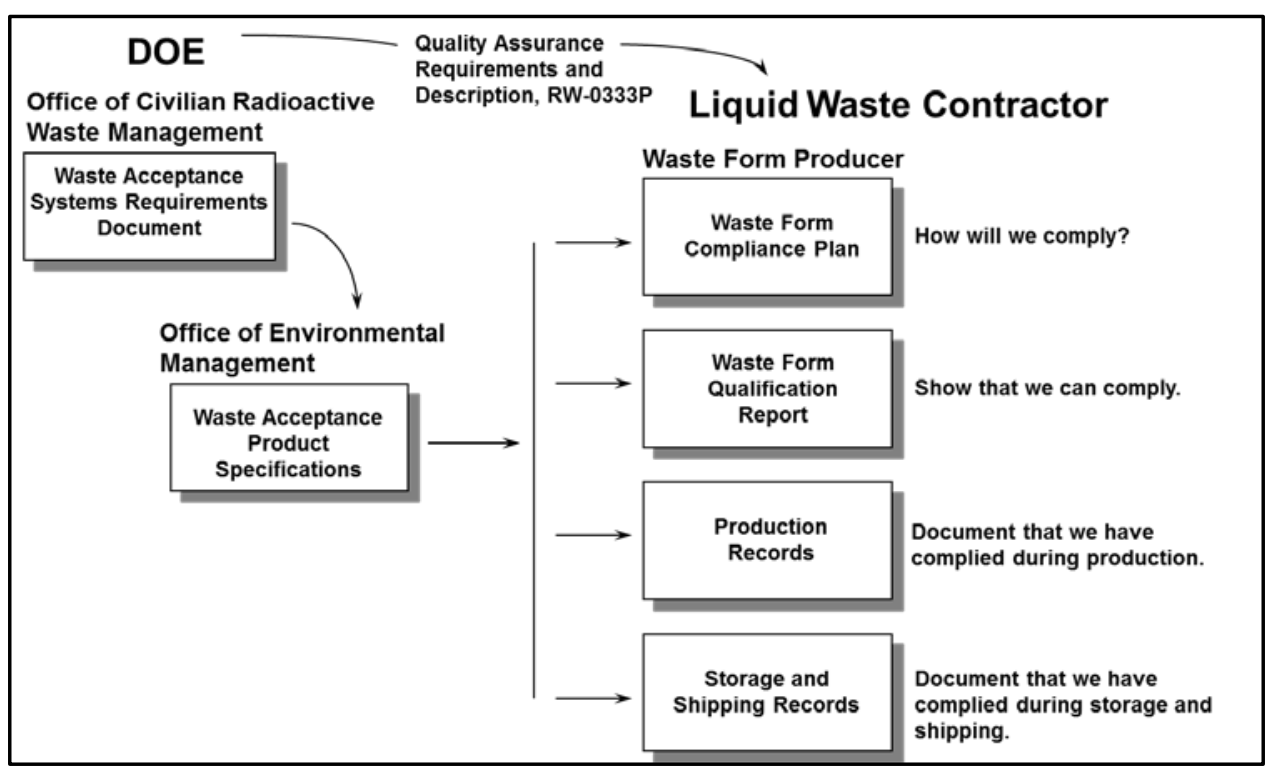

Figure 2-1. Waste Form Requirements and Compliance Documents

The WA-SRD establishes waste acceptance technical requirements for the DOE Civilian Radioactive Waste Management System including the acceptance criteria imposed on the high level waste form. The EM-WAPS are the technical specifications the waste form producer must meet to ensure acceptance of the waste form. The EM-WAPS is divided into sections addressing the waste form specifications, canister specifications, canistered waste form specifications, quality assurance specification, and documentation and other requirements.

As part of the program to startup the DWPF and produce a qualified glass product, the SRS contractor responsible for the liquid waste program (currently the Savannah River Remediation LLC (SRR)), along with the Savannah River National Laboratory (SRNL) (formerly known as Savannah River Laboratory and Savannah River Technology Center), established a WCP [47] and a series of Waste Form Qualification Reports (WQR). [48 - 60] The overall strategy for complying with the EM-WAPS is to assure the quality of the product (i.e., canistered waste form) meets the EM-WAPS criteria over the range of anticipated chemical compositions and operating conditions. The strategy to prove compliance for DWPF included laboratory-scale, pilot-scale, and radioactive testing prior to and during radioactive operations as well as confirmation of controls during cold commissioning of the DWPF. Many of the specifications require that the canister and waste form be well-characterized before production of the actual waste forms begins. Others were satisfied through full-scale operations using non-radioactive simulated waste. The remaining EM-WAPS specifications address canistered waste forms produced during radioactive operations.

The WQR is a compilation of the results of the testing and analysis programs that demonstrate that the product can comply with the EM-WAPS utilizing the strategies identified in the WCP. The WQR for DWPF is thirteen volumes and is intended to be a living document as new information is obtained on the SRS HLW disposition process. Appendix A of this report is a table that crosswalks the requirements in the EM-WAPS to the DWPF WCP and WQR.

When discussing the EM-WAPS requirements, one important difference to note between SRS and Hanford waste is the hazardous waste determination. Early in the DWPF flowsheet development process, SRS performed an evaluation to determine whether the waste should be 
considered listed. This evaluation concluded that a listing was not required and controls have been put in place to ensure that listed wastes are not transferred to the SRS Tank Farm. The South Carolina Department of Health and Environmental Control and the Environmental Protection Agency concurred with this determination. The other aspect that could have made the waste form hazardous was by being characteristically hazardous. Glass waste forms are not considered ignitable, corrosive, or reactive. Hence the only potential characteristic that remained was toxicity. Once it was shown through performance of the Toxicity Characteristic Leaching Procedure (TCLP) that it was not toxic, all hazardous designations could be removed. Therefore, SRS waste is not considered a listed or mixed waste like Hanford. A description of this determination is provided in WQR Volume 13. [60]

The records generated during production for each canistered waste form are captured in the Production Records. The Production Records provide evidence that an acceptable waste form was produced. Data on each macro-batch ${ }^{1}$ and each canister is collected into a "wallet", and these are collected into the Production Records. Figure 2-2 is a representation of how these records are compiled. The glass sample data for the canister wallet is a compilation of all of the process batch data during the macro-batch and a calculated average from all the process batches for that macrobatch, see Section 3.1 for additional information on this sample.

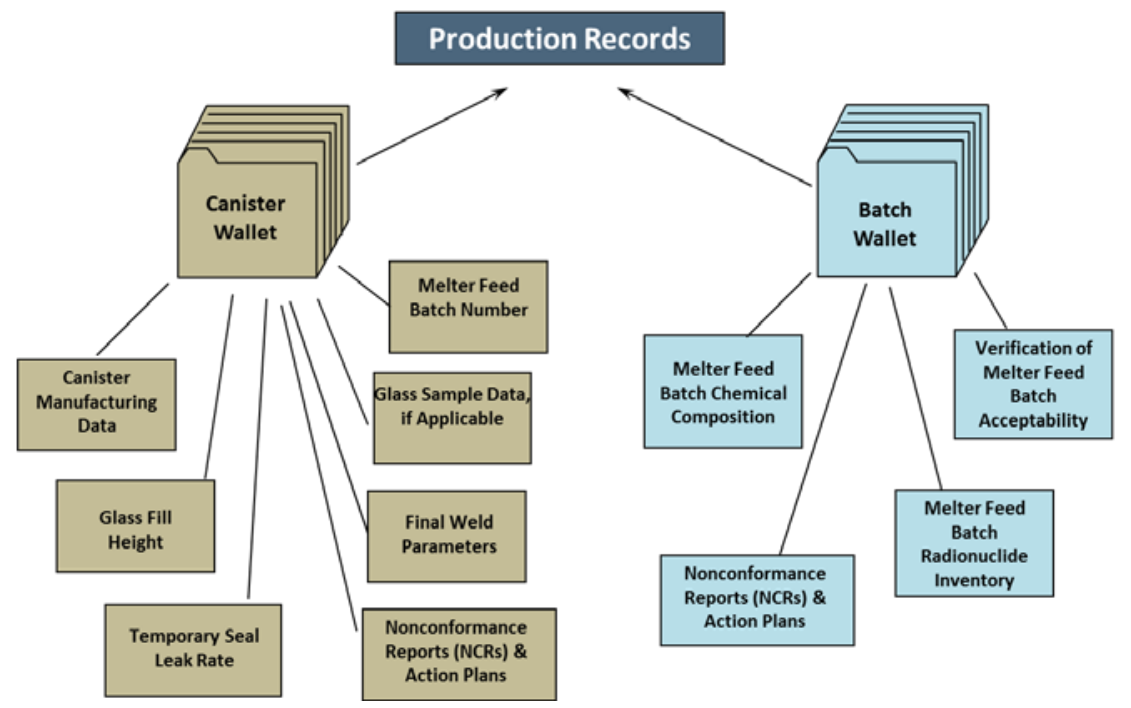

Figure 2-2. Canistered Waste Form Production Records

Changes to the waste acceptance documentation are formally controlled. Changes to the WCP require approval by DOE. The waste acceptance program defines which changes require DOESavannah River (DOE-SR) approval and which require DOE-Headquarters (DOE-HQ) approval. To assist in the control of changes the DWPF Waste Acceptance Reference Manual [25] has been established to identify items/activities that impact the repository quality assurance requirements

\footnotetext{
${ }^{1}$ The "macro-batch" is a key concept for compliance with the Chemical Composition During Production Specification (1.1.2), the Radionuclide Inventory During Production Specification (1.2.2), the Product Consistency Specification (1.3) and the International Atomic Energy Agency (IAEA) Reporting Specification (1.6). The feed to the DWPF will remain relatively constant for extended periods of time. The sludge will be prepared in 400,000-700,000 gallon $(1,500,000-2,700,000 \mathrm{~L})$ batches. The salt effluent feed will also be prepared in similar batches. The periods of relatively constant feed constitute macro-batches, which the DWPF will treat as the "waste types" referred to in the above mentioned specifications. [47, App 1.200.1]
} 
(RW-0333P [46]), the WCP, the WQR, or the ability to produce an acceptable glass product. A listing of the items/activities important to the waste acceptance process is included in Section 3 of the DWPF Waste Acceptance Reference Manual. To determine if an item/activity has an impact, the proposed change is challenged with the following:

$>$ If the failure of an item or activity could result in a nonconforming canistered waste form.

$>$ If a design change to an item could affect waste qualification results or affect the canistered waste form's ability to comply with the EM-WAPS.

$>$ If the item/activity generates data for the Production Records.

$>$ If the activity generates waste qualification data.

\subsection{DWPF HLW Glass Product Control Program and Waste Feed Acceptance Overview}

\subsection{Elements of the Glass Product Control Program}

The primary means of controlling the durability of the glass waste form that is produced in the DWPF is the GPCP. The DWPF GPCP is described in WQR Volume 6 [53], while a detailed discussion of the GPCP technical basis is provided in WQR Volume 5. [52] The GPCP is based on the operating philosophy that the best way to ensure an acceptable glass product is through control of the composition of the feed to the melter. This assumption holds as long as DWPF operates within the process parameters that have been developed to ensure homogeneity of the feed in the chemical processing steps and the melter operates within the established limits. The process is controlled so the glass product that is produced performs at least two standard deviations below the mean Product Consistency Test (PCT) results of the benchmark Environmental Assessment (EA) glass per EM-WAPS Specification 1.3. [42] The control program ensures acceptable glass is produced through:

$>$ Control of the feed composition at the last feed preparation vessel (the Slurry Mix Evaporator (SME)).

$>$ Providing documented evidence that control is achieved.

$>$ A robust program that can handle changes.

Multiple peer and technical review groups have provided guidance and input to the DWPF operating strategy both before start-up and since radioactive operations began. The control strategy is based on several key constraints or inputs:

$>$ Glass rework is not possible, thus a feed-forward process control strategy is paramount.

$>$ Blending multiple waste streams in the facility must be accounted for (e.g., sludge and salt processing streams resulting from current Actinide Removal Process (ARP) and/or Modular Caustic Side Solvent Extraction Unit (MCU) processing and/or ultimately from the Salt Waste Processing Facility (SWPF)).

$>$ Multiple waste types exist in Tank Farm that may require blending and/or treatment (such as Al-dissolution).

$>$ Critical glass properties cannot be measured in situ ${ }^{2}$, thus models relating glass properties to composition must be developed and implemented at a high confidence level. [14]

\footnotetext{
${ }^{2}$ During production, DWPF uses the analysis of the SME product as the primary process control point. Although critical to the technical underpinning of the control process, production cannot wait on a series of laboratory tests (such as a 7-day PCT to measure durability or measurements of liquidus temperature and/or high temperature viscosity) to be completed before making acceptability decisions regarding the melter feed. Thus, models that relate glass composition to the measured composition of the SME samples are used to predict glass properties and those predictions are compared to pre-defined acceptance constraints related to processing (liquidus temperature and viscosity) and product quality (or durability) to determine acceptance.
} 
> Sampling/characterization of sludge from the Tank Farm and during DWPF processing (Sludge Receipt and Adjustment Tank (SRAT) and SME analysis) is not exact, therefore the control strategy must account for uncertainties associated with compositional and measurement uncertainties.

$>$ Melter processing constraints to protect materials of construction and melter design life impact glass properties. These include (but are not limited to) liquidus temperature $\left(T_{L}\right)$ and glass viscosity $(\eta)$.

$>$ Established control strategy should apply (or be adaptable) over facility lifetime.

The GPCP consists of the following elements [53]:

$>$ Qualification of waste

- Ensures that program bases are valid for each Tank Farm waste batch (both sludgeonly processing as well as coupled operations (processing of sludge and salt)), is performed to DOE/RW-0333P requirements, and includes

o Characterization of the salt and sludge batch for reportable element determination to meet WAPS requirements during processing.

o Defining a frit for each sludge batch that will produce an acceptable glass for either sludge-only or coupled operations.

o Demonstrating the DWPF process including fabrication, characterization, and testing of a fabricated glass using the qualification sample.

o Performance of a glass variability study to confirm the applicability of the durability models to the sludge batch compositional region of interest, which is defined by the sludge, salt stream, and frit composition as well as the waste loading (WL) interval of interest.

o Verification of the current sampling regimen/analytical protocol, if necessary, to ensure that the sludge does not contain a new or "troublesome" component for which the analytical methods or digestion techniques will not accommodate and thus negatively impact the compositional analysis.

Sampling/Analysis of the SME batch

- Sampling and analysis of the SME is the critical control point in the DWPF process and is governed under DOE/RW-0333P requirements.

- Once the SRAT product is transferred to the SME, frit is added to target a specific blend point (or targeted WL) and samples of the melter feed are obtained.

- The representative melter feed samples from the SME are analyzed for chemical composition and the results are used for reporting the composition on a macro-batch basis. Both the individual process batches and the overall macro-batch average composition are reported.

- The number of samples is based on the compliance strategy for EM-WAPS Specification 1.3. Detailed testing was performed before start-up to determine the number of samples that would be required and to address the error associated with this sampling and analyses. (See section 3.3 for a discussion of sampling to support GPCP and feed acceptance.)

Evaluation of feed acceptability

- The analyses of the SME samples are used as inputs to the Product Composition Control System (PCCS) models to predict various process and product durability properties of the glass. [14] The PCCS is the tool that the DWPF uses to consistently evaluate the glass composition. The PCCS is a statistical software system that is used to determine the acceptability of the material in the SME. 
- The predicted properties are then compared to a series of pre-defined constraints to ensure both product quality (durability) and processing constraints (such as $\eta$ or $T_{L}$ ) are acceptable accounting for appropriate errors (measurement and property related uncertainties).

- If all constraints are simultaneously satisfied, the SME material is transferred to the Melter Feed Tank (MFT) and ultimately to the melter.

- If any of the pre-defined constraints are not satisfied, the SME batch must be remediated, resampled and analyzed. The re-measured compositions are evaluated by PCCS to demonstrate compliance. Remediation (which is a rare occurrence) usually takes the form of adding more frit (to lower WL) or more sludge (to increase WL).

\section{Verification/Reporting}

- Required information (chemical composition, projected PCT results, and radionuclides) is reported in the Production Records; radionuclides are determined from the EM-WAPS Sample, which is pulled from Tank 40 for the sludge once per macro-batch, and from the salt batch analyses that have been processed with that macro-batch.

Confirmatory Glass Sampling

- Once per sludge batch, glass samples are taken and analyzed; currently, a minimum of one glass sample is characterized for elemental composition and radionuclide content, and subjected to the Product Consistency Test (PCT) to assess durability. A second sample has been taken for the last several sludge batches and has been archived. The intent of the pour stream characterization (composition and PCT analysis) is to provide additional and direct confirmation (the first being the SME acceptability process) that the glass being processed through the melter is an acceptable waste form meeting repository requirements and that all reportable constituents have been identified during analyses of the feed streams. 
Figure 3-1 shows the DWPF product control process with the product control envelope defined. [53]

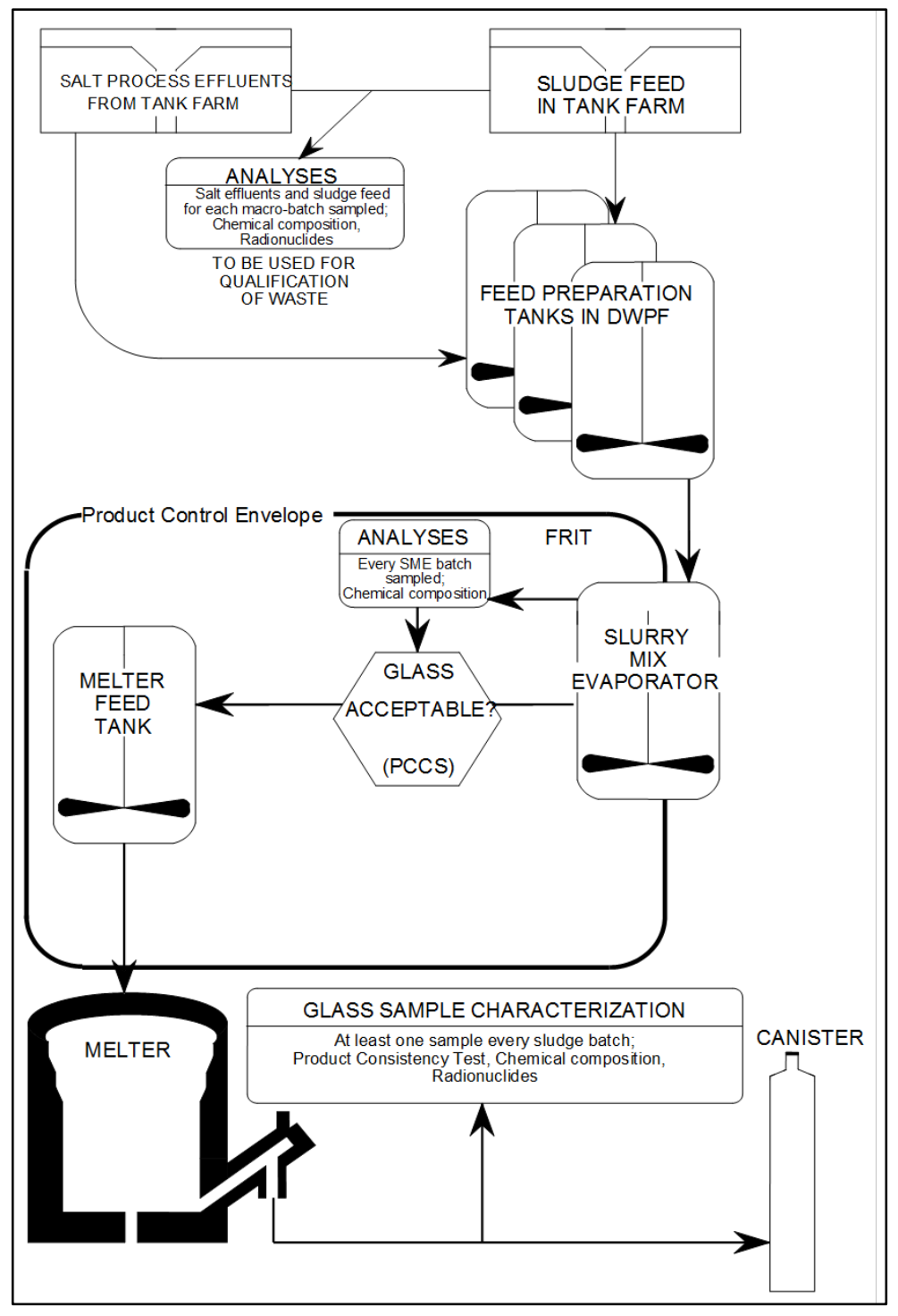

Figure 3-1. DWPF Product Control

\subsection{Elements of Waste Feed Acceptance}

To control the process and to ensure the feed process is within the facility design basis and can produce an acceptable glass waste form, each step in the process has controls. This includes the interface between processes. At SRS, the control of the interfaces is managed typically through two documents: the waste acceptance criteria (WAC) and the waste compliance plan. The receiver (e.g., DWPF) prepares the WAC to define requirements, and the sender (e.g., Tank Farm) establishes the waste compliance plan for how the WAC will be met. Figure 3-2 is a simplified depiction of the interfaces in the SRS Liquid Waste System. Taking one set of interfaces from this figure as an example, the DWPF has a WAC document [24] for sludge transfers that the Tank Farm must meet in order to transfer the sludge (waste compliance plan). This same DWPF WAC also contains requirements for the salt transfers to the Actinide Removal Process Facility, Building 512-S, and/or DWPF. However, before DWPF can accept the salt or 
sludge transfers, DWPF must also show compliance with the Tank Farm WAC [22] because of the recycle returns to the Tank Farm. To help manage the process for ensuring the feed to DWPF is acceptable, the Sludge Batch Checklist [17] is used to document the process steps that have been completed.

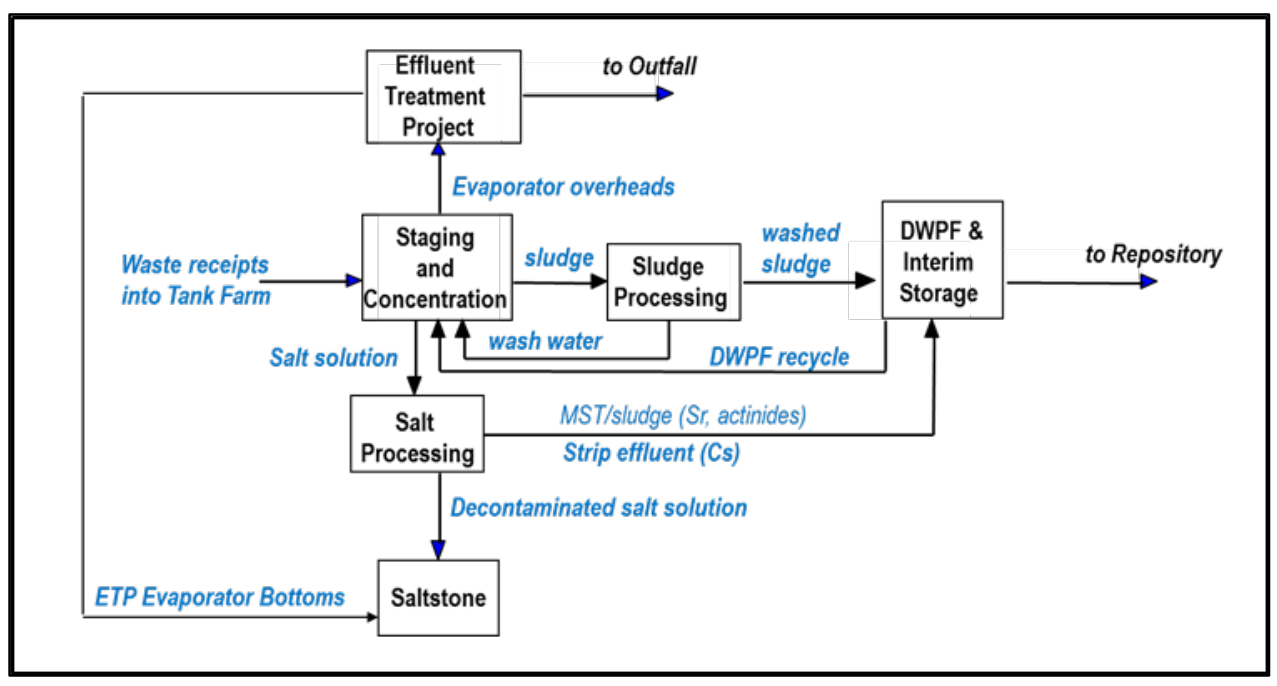

Figure 3-2. Simplified SRS Liquid Waste System Interfaces

Whereas the WA-SRD $\rightarrow$ EM-WAPS $\rightarrow \mathrm{WCP} \rightarrow \mathrm{WQR}$ relationship for DWPF, depicted in Figure 2-1, is in place to ensure that an acceptable glass waste form will be produced, several criteria have also been identified to ensure that the processing in DWPF will meet environmental emissions requirements, maintain safety basis assumptions, safeguard personnel from exposure, and protect the materials of construction. These criteria are subject to change as more information on DWPF processing becomes available and as processes change throughout the SRS Liquid Waste System. The description of the acceptance criteria in the WAC includes the criteria, criteria type (limit or target) ${ }^{3}$, and computational technique. A table of the criteria in the WAC for acceptance of feed to DWPF is included in Appendix B. The table includes a column listing the source for the WAC limit or target. In many cases the limit or target in the WAC is more conservative than the limit or target in the GPCP.

\subsection{Sampling to Support Glass Product Control Program and Feed Acceptance}

Figure 3-3 is a simplified process diagram with sample points indicated. A detailed sludge batch preparation and qualification flowchart is included in Appendix C. The sampling program to support qualification and feed acceptance was summarized during the May 2013 meeting between SRS and Hanford personnel on Waste Feed Qualification [26, 29], and in the 2012 report SRNL Phase 1 Assessment of the WTP Waste Qualification Program. [20] Table 3-1 provides a brief summary of the purpose of each sample and the associated testing performed to qualify or accept the sludge for DWPF. The Sludge Batch Checklist [17] documents that the prerequisite sample characterization and testing and other facility requirements have been completed.

${ }^{3}$ The DWPF WAC [24] defines the terms limit and target as:

- LIMIT: a type of acceptance criteria that, if not satisfied, will have an adverse impact on repository requirements (EM-WAPS) or DWPF Safety Basis.

- TARGET: a type of acceptance criteria that, if not satisfied, will have an adverse impact on cost or attainment (process throughput). 


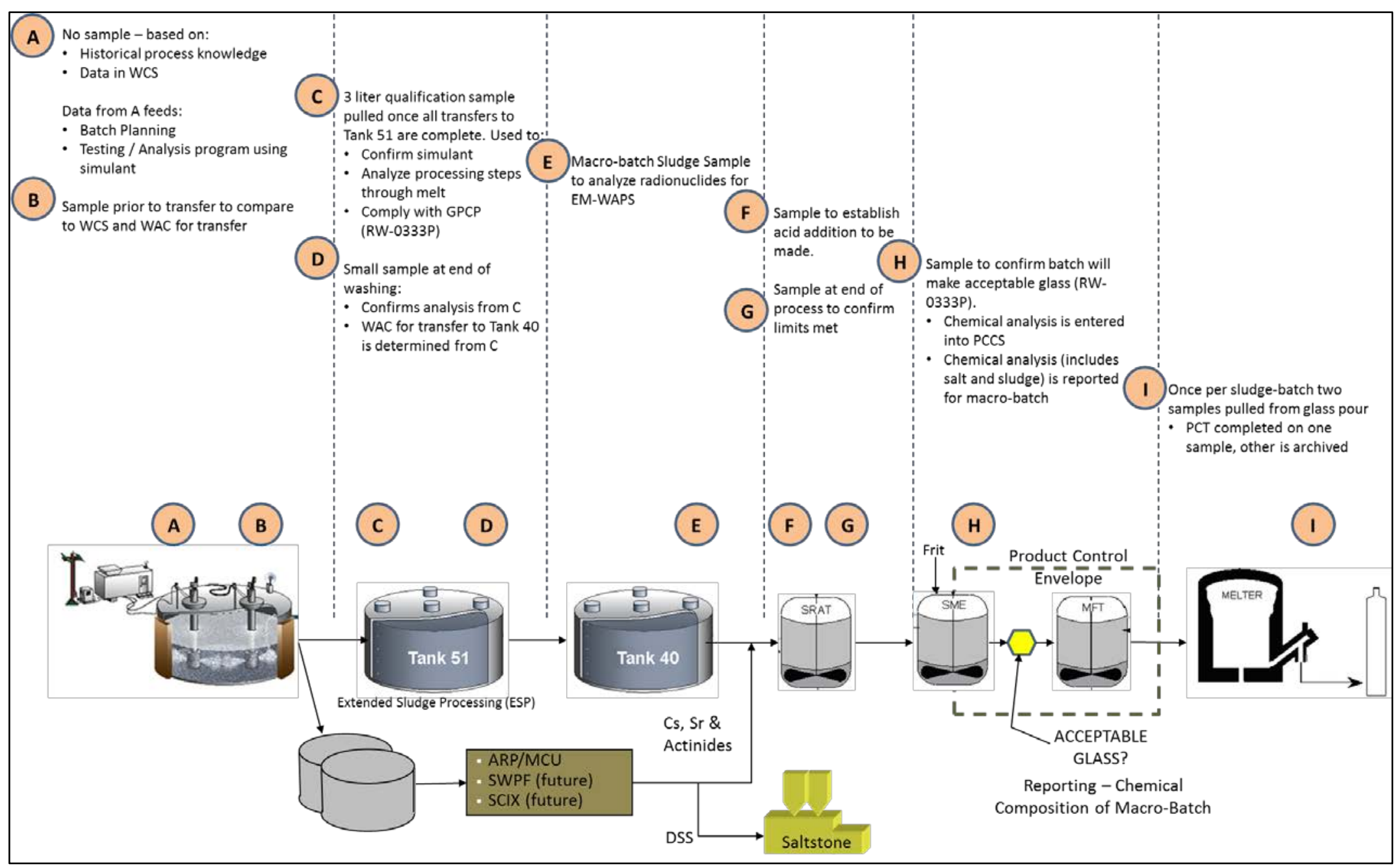

Figure 3-3. Sampling Overview Process Diagram 
Table 3-1. Summary of Samples

\begin{tabular}{|c|c|}
\hline Point & Summary \\
\hline A & $\begin{array}{l}\text { No Sample - Information is gathered from the Waste Characterization System (WCS) and } \\
\text { historical knowledge of process to ensure that the blended tanks will produce an acceptable } \\
\text { glass. This data feeds batch planning and the SRNL testing and analysis program using } \\
\text { simulants. }\end{array}$ \\
\hline B & $\begin{array}{l}\text { After the volume to be transferred is well mixed, a sample is taken and compared to the } \\
\text { WCS data. This analysis supports batch planning and Tank Farm operations (i.e., Tank } \\
\text { Farm WAC). }\end{array}$ \\
\hline $\mathrm{C}$ & $\begin{array}{l}\text { Qualification Sample - Once all of the sludge and other solids components that may impact } \\
\text { the sludge oxide composition have been transferred to Tank 51, a 3L qualification sample is } \\
\text { pulled for commencement of qualification activities to satisfy the GPCP and work is } \\
\text { performed to RW-0333P requirements. No additional transfers can occur to Tank } 51 \text { unless } \\
\text { a representative sample of the material is taken and appropriately blended with the } \\
\text { qualification sample in SRNL so it can be included as part of the qualification process. The } \\
\text { only exception is the supernatant Na, since additional washing is typically performed after } \\
\text { the qualification sample is pulled. The washing process is fairly well predicted and is } \\
\text { demonstrated in the laboratory with the qualification sample. The wash endpoint, or Na } \\
\text { concentration, is also confirmed with sample D. }\end{array}$ \\
\hline $\mathrm{D}$ & $\begin{array}{l}\text { Small confirmation sample near the end of the Extended Sludge Processing (ESP) activities } \\
\text { in Tank } 51 \text { to verify the composition. This allows any adjustments to be made should the } \\
\text { results not match or bound those of the qualification sample. In general, the qualification } \\
\text { sample is used to confirm the WAC for transfer to Tank } 40 \text { is met. }\end{array}$ \\
\hline $\mathrm{E}$ & $\begin{array}{l}\text { EM-WAPS Reporting Sample - Primary goal is to determine reportable radionuclides for } \\
\text { macro-batch, elemental composition is also characterized. The analysis includes the } \\
\text { bounding assumption that all measured radionuclides end up in the final glass waste form. } \\
\text { This assumption is based on the DWPF melter operating conditions of a cold cap and } \\
\text { slightly reducing conditions result in minimal volatility (Tc and Cs in particular). Carbon- } \\
14 \text { is known to be extremely volatile, so it is not measured since it is assumed to volatize } \\
\text { during melting. Typically the sample is analyzed in quadruplicate with reference standards, } \\
\text { where applicable. Radionuclide data is used to project reportable radionuclides over } 1100 \\
\text { years. The sludge sample (EM-WAPS) is one of the contributors to the macro-batch } \\
\text { reportable radionuclides with the salt stream providing the other constituents to be } \\
\text { considered. The salt contribution is estimated from the salt batch qualification sample. }\end{array}$ \\
\hline $\mathrm{F}$ & $\begin{array}{l}\text { SRAT receipt samples are taken to determine the acid addition strategy (both amounts and } \\
\text { splits of nitric and formic acid) to complete required Chemical Process Cell (CPC) } \\
\text { activities (target REDOX, adjust rheology, reduce manganese, remove } \mathrm{Hg} \text {, etc). Four } \\
\text { samples are analyzed for this estimation. }\end{array}$ \\
\hline $\mathrm{G}$ & $\begin{array}{l}\text { SRAT product samples are used to confirm process parameters have been met and to } \\
\text { determine the frit addition amount (or waste loading target) once the SRAT product is } \\
\text { transferred to the SME. }\end{array}$ \\
\hline $\mathrm{H}$ & $\begin{array}{l}\text { Acceptable Glass Sample - Once the frit has been blended with sludge in the SME at the } \\
\text { targeted waste loading, samples are taken, vitrified, and compositionally measured. The } \\
\text { compositional analysis is used as input into PCCS to predict the critical process and } \\
\text { product performance properties, and those predictions are compared to acceptance criteria } \\
\text { (glass acceptability and melter flammability). This process is referred to as SME } \\
\text { acceptability. If all acceptance criteria are simultaneously met, the melter feed is transferred } \\
\text { to the MFT. The results of the analyses are documented in the Production Records } \\
\text { individually and as an overall average for the macro-batch. This part of DWPF's analyses is } \\
\text { under EM/RW-0333P controls. [14, } 46,49,52]\end{array}$ \\
\hline
\end{tabular}




\begin{tabular}{|c|l|}
\hline Point & Summary \\
\hline I & $\begin{array}{l}\text { Pour Stream Sample - At least one pour stream sample is taken for each sludge batch. } \\
\text { Currently DWPF takes two pour stream samples per sludge batch. One sample is subjected } \\
\text { to chemical composition analyses and durability testing, and the other is archived. Analyses } \\
\text { verify reportable elements, some radionuclides (others are calculated), and PCT results are } \\
\text { compared to model predictions and reported. Therefore, the PCT results provide an } \\
\text { additional confirmation that an acceptable glass is being produced and that the durability } \\
\text { model being used during the SME acceptability process are applicable to the composition } \\
\text { region being processed. }\end{array}$ \\
\hline
\end{tabular}

Due to the fact that Tank 51 material is transferred onto a heel of Tank 40, results from laboratory analyses of tank contents, tank volumes and existing tank heel volumes are evaluated using the glass property models from the PCCS to determine appropriate Tank 40 blending. In addition, the projected Tank 40 composition from those inputs is used to identify candidate frits for that sludge batch and establishes a baseline from which CPC studies can be initiated. SRR and SRNL can provide projections of Tank 40 as a function of various wash endpoints to determine the downstream impacts on frit selection, projected operating windows (defined as the WL interval over which the frit - sludge/salt mixture is deemed acceptable by PCCS and the related constraints), and CPC processing windows. These assessments allow for optimization of washing and blending points to maximize throughput.

With the waste qualification sample pulled, after the sludge batch is assembled in Tank 51, SRNL completes the following: sludge characterization, sludge washing or concentration, as necessary, demonstration of the SRAT cycle, demonstration of the SME cycle, and fabrication of glass for PCT durability testing. Offgas composition results from testing of the qualification sample are scaled to full-scale values for DWPF production. An assumption is made that the physical property measurements from the samples taken during the demonstration test will be adequate to assess whether the waste can be physically mixed, pumped, etc. during DWPF processing; therefore, these processes are not scaled from the demonstration test. Additional testing may be completed to support processing activities such as evaluation of melt rate and waste throughput to optimize the frit and flowsheet testing with the composition to be processed in DWPF (versus the qualification sample composition that does not factor in the heel of Tank 40).

As previously mentioned, PCCS is a tool used as part of the GPCP to evaluate SME acceptability decisions. The PCCS models factor in the analytical and sampling errors of the DWPF facility when predicting the properties of the glass. The glass properties that are assessed with PCCS include (but not limited to) glass durability, viscosity, liquidus temperature, homogeneity, and solubility limits. The applicability of the durability/composition models are evaluated during the qualification activities performed by the laboratories before acceptance of the sludge batch. More specifically, a glass variability study is performed to ensure that the durability models apply over the anticipated glass composition region. Solubility limits are also evaluated and updated if necessary during the qualification process. The initial solubility limits were conservatively set but further definition of these limits has proven to be necessary in some cases. For example, the initial $\mathrm{SO}_{4}$ limit in PCCS was established as $0.4 \mathrm{wt} \% \mathrm{SO}_{4}$ in glass based on work performed to that point. However, when the initial limit was established, the dependency on glass composition was not established. Therefore, when the need arose to increase the limit due to process changes (acceptance of excess canyon material and washing to $>0.5 \mathrm{M} \mathrm{Na}^{+}$), a new dependency of glass composition with sulfate solubility was established. At the time, $0.4 \mathrm{wt} \%$ was the limit but has transitioned up to $0.6-0.65 \mathrm{wt} \%$ depending on the sludge batch and associated glass composition. 
Experience and maturity of DWPF's operations provides key technical feedback, which serves as the basis for the development of alternative strategies to support continuous improvement activities associated with both flowsheet development activities as well as qualification requirements. As will be discussed in a subsequent section, changes or improvements to the PCCS models, associated limits/constraints, and alternative processing strategies have occurred since the startup of the DWPF as new data and information becomes available on the processing regions anticipated for DWPF and glasses within these regions are tested. In addition, glass formulation strategies have shifted from a "one frit fits all" concept (i.e., a single multicomponent frit composition that would work for every batch) to tailoring specific frits for each sludge batch ${ }^{4}$ in order to optimize sludge preparation, increase waste loading and improve throughput - all of which have a positive impact on reducing the overall mission life of the Tank Farm and DWPF facilities. These efforts have served as technical bases for DWPF's continuous improvement efforts since initial DWPF operations began in 1996.

\subsection{Compliance Strategy Examples}

The previous two sections addressed the framework of requirements for the waste form and the SRS glass product control program. This section presents examples of the SRS compliance strategy for two of the specifications in the EM-WAPS: 1.1.1 Chemical Composition Projections, and 1.1.2 Chemical Composition During Production. These may be relevant to the protocols being developed for other HLW systems.

The DWPF WCP, Part 3, Item 100 addresses EM-WAPS: 1.1.1 Chemical Composition Projections.

\subsection{CHEMICAL SPECIFICATION}

The waste form is borosilicate waste glass.

\subsubsection{Chemica1 Composition Projections}

In the WQR, the Producer shall project the chemical composition, identify crystalline phases expected to be present, and project the amount of each crystalline phase, for each waste type. The method to obtain the required data shall be described by the producer in the WCP. The data shall be provided in the WQR. Waste form compositions not available for reporting in the initial WQR shall be included in an addendum to the WQR. [47]

Part 3, Item 100 includes the compliance strategy for meeting EM-WAPS Specification 1.1.1, which centers on defining a set of projected glass compositions that span the range of glass properties expected to be produced in DWPF. When the WCP was written, the projected compositions depended on the following:

$>$ The compositions of wastes (e.g., high Al-based sludge (H-Modified PUREX Process (HM)) or high Fe-based sludge (Plutonium/Uranium Extraction (PUREX)) currently stored in the Tank Farms.

$>$ Anticipated blending schemes for the wastes in the Tank Farm.

$>$ The expected composition(s) of the glass frit to be used.

\footnotetext{
${ }^{4}$ In order to meet DWPF WL obligations and to provide robustness to both sludge-only and coupled operations, SRNL evaluates new frit compositions for each sludge batch. Once the frit composition has been recommended for DWPF processing, an off-site vendor fabricates the frit composition to meet both compositional and particle size specifications.
} 
The rationale for selecting these compositions is provided in the WCP, while the specific details and results of the assessment are provided in the WQR. The waste and frit composition information is only part of the required information to meet EM-WAPS Specification 1.1.1 and other items needed included:

$>$ An integrated flowsheet model to convert the waste and frit compositions into projected glass compositions.

$>$ The temperature profile expected for DWPF canisters during filling with glass and subsequent cooling.

$>$ Identification of the crystalline phases and determination of the amounts of each from application of the thermal profile to the projected glass compositions.

A summary table of the projected DWPF glass compositions is provided in the WCP based on this approach as well as a high-level description of the testing and validation used to determine the required information. [47] Graphically, the tasks needed to satisfy EM-WAPS Specification 1.1.1 are given in Figure 4-1. The items in the hexagons identify the information that was documented in the WQR including information on the compositions, flowsheet model, and anticipated crystalline phases. The requirements for compliance with this specification were satisfied before DWPF radioactive operations commenced as these are projections not production results. For this particular specification, the details of the approach, necessary data, and technical basis are provided in Volume 1 of the WQR. [48]

Although the projections were based on the best information available at the time, there was recognition that the compositions might not reflect the exact composition of any waste form subsequently produced, but the properties of the glass produced would be bound by the range of glass properties tested. An approach was outlined for the qualification of future waste glass compositions should future site processes impact the glass properties and included updating the affected WQR volumes. 
SRNL-STI-2013-00585

Revision 0

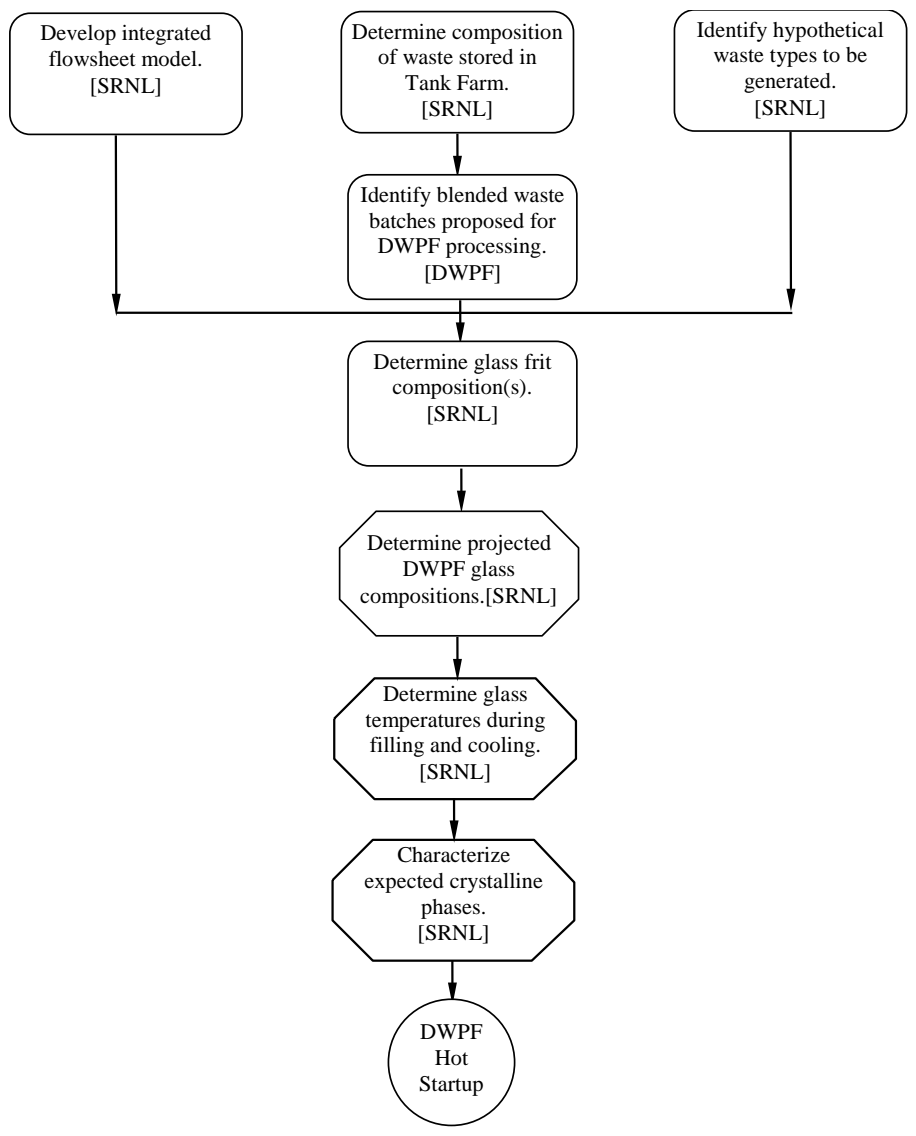

Figure 4-1. Tasks Planned to Satisfy EM-WAPS Specification 1.1.1, Chemical Composition Projections

The DWPF WCP, Part 3, Item 200 addresses EM-WAPS: 1.1.2 Chemical Composition During Production.

\subsubsection{Chemical Composition During Production}

In the Production Records, the Producer shall report the oxide composition of the waste form. The reported composition shall include all elements, excluding oxygen, present in concentrations greater than 0.5 percent by weight of the glass, for each waste type. The Producer shall describe the method to be used for compliance in the WCP. An estimate of the error of the reported composition and the basis for the estimate shall be reported in the WQR. [47]

Part 3, Item 200 details the compliance strategy for reporting the chemical composition during production, and is based on the relatively constant nature of feed to the DWPF over each sludge and salt batch (i.e., macro-batch). For EM-WAPS Specification 1.1.2, samples of each sludge and salt batch are taken and analyzed by SRNL to determine the reportable components before the start of DWPF processing. For conservatism, all elements present at $1 \mathrm{wt} \%$ are reported in the waste, which covers variation in potential waste loading and sampling/analytical uncertainty. [49, WQR-2 Sections 4 and 8] During processing, DWPF measures each melter feed process batch from the SME tank to determine the reportable elements greater than $0.5 \mathrm{wt} \%$. The average elemental composition for all process batches from that macro-batch is then reported in the Production Records with the appropriate calculated standard deviations. Errors associated with 
this strategy were determined prior to and during DWPF qualification runs through analyses of feed and glass samples and considered feed non-uniformity, sampling variability, variability due to the analytical system, error in calculation of macro-batch composition, and process variability. Finally, a glass sample is taken and analyzed at SRNL related to each macro-batch to verify the reportable elements. [47] Figure 4-2 graphically presents the steps that were taken to demonstrate that the requirements of EM-WAPS Specification 1.1.2 could be met during production. [47] The chemical composition results from processing are documented in the Production Records as indicated by the oval at the end of Figure 4-2.

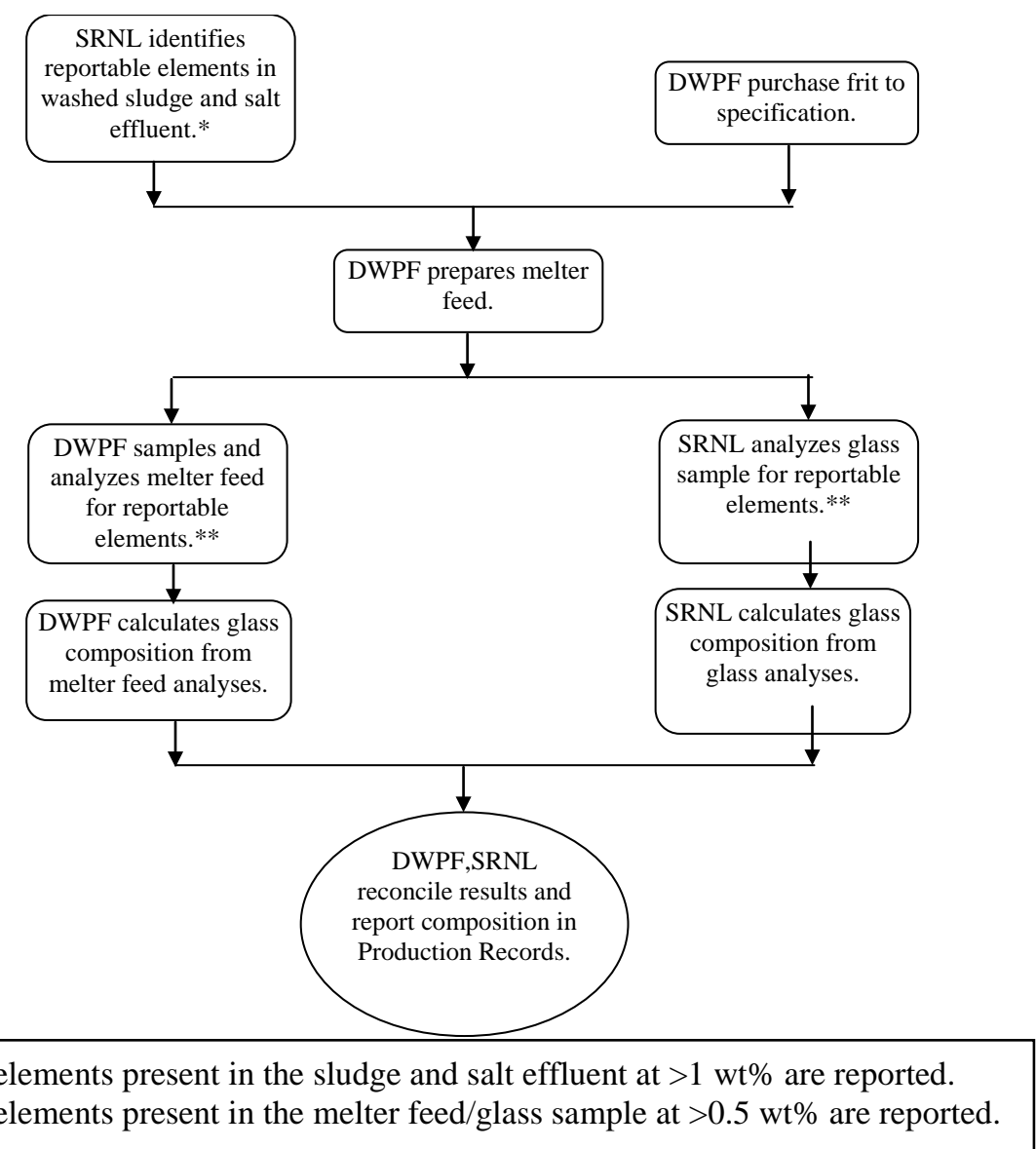

Figure 4-2. Strategies to Determine Chemical Composition During Production (EM-WAPS Specification 1.1.2)

In order for this strategy to be successful, the following items had to be developed:

$>$ Equipment and methods to sample the slurry feed material in the DWPF process vessels.

$>$ Methods for analyses of the major components in each process batch, including demonstration of these methods in the laboratory with simulants and in remote facilities with actual radioactive waste.

$>$ Procedures for the analytical methods to be used in the DWPF.

$>$ A relationship between feed composition and glass composition.

$>$ Estimation of the error in the reported composition. [47]

Development of this information occurred ahead of DWPF startup, but was confirmed during DWPF qualification runs/startup testing. The results were documented in WQR Volume 2. [49] 
WQR Volume 2, like the WCP, reflects more of the changes that have occurred since DWPF startup because the data generated relates more to the actual DWPF processing (i.e., Production Records) versus EM-WAPS Specification 1.1.1 that dealt strictly with projected compositions.

\subsection{Overview of DWPF Startup Program and Qualification Runs}

Prior to conducting the qualification program in the DWPF facility, many tests and analyses were performed to establish compliance strategies and to demonstrate compliance with sections of the EM-WAPS. These included: laboratory and pilot scale demonstrations of the DWPF feed preparation process; crucible melts and $1 / 100^{\text {th }}$ and $1 / 9^{\text {th }}$ scale melter runs with cold feed; crucible melts and $1 / 100^{\text {th }}$ scale melter runs with actual waste, and up to full-scale testing of mixing and sampling of processing vessels with simulants. [1, 6, 27, 32, 49, 51, 52]

The qualification program was integrated into the DWPF Startup Test Program. The Startup Test Program included water runs, chemical runs, waste qualification runs, and proficiency runs. All of these were completed prior to the introduction of radioactive material into the facility. [1, 6, 27, 32] Table 1.200.1 (DWPF Startup Test Program - Test Index) in the WCP [47] is a listing of the tests conducted during the Startup Test Program, the listing highlights tests which have significant waste acceptance process components.

\section{$>$ Water Runs and Cold Chemical Runs}

- Tested equipment and piping up to the melter, then simulated feed and raw materials were introduced to perform the FA-13 test. FA-13 was a functional test of the melter, and accomplished the flushing of the startup frit out of the melter in preparation for the waste qualification runs.

- Melter heat up with startup frit, 16 canisters filled as part of the FA-13 testing.

- Runs began in 1992, and the first glass pour was in 1994.

Waste Qualification Runs - Integrated operation of the processing equipment as part of the DWPF Startup Test Program and demonstration of the DWPF process and facility's ability to comply with the EM-WAPS.

- Demonstrated effectiveness of GPCP, including melter feed homogeneity and sample representativeness, over the range of anticipated compositions including both small and large changes in feed composition.

- Specific compositions were selected based on the thesis that if the composition/PCT correlation has been used properly to judge the acceptability of the feed, the only possible cause of failure of the GPCP is segregation of the feed. This will occur only if the rheological properties of the material are not consistent with good mixing in the process vessels. [32]

- Four campaigns of varying feed rheologies and glass viscosities:

o WP-14 objective was to provide data to characterize the flow of material through the melter for normal small changes in feed composition using a non-radioactive dopant in the feed.

o WP-15 objective was to provide data to characterize the flow of material through the melter for large changes in feed composition, which lead to low glass viscosity and high glass density (simulated PUREX waste).

o WP-16 objective was to provide data to characterize the flow of material through the melter for large changes in feed composition, which lead to high glass viscosity and lower glass density (simulated HM waste), and measure canister cooling temperatures for two canisters filled on the melter pour turntable.

o WP-17 objective was to provide data to characterize the flow of material through the melter for large changes in feed composition, going from 
high glass viscosity and lower glass density back to a composite type feed, and demonstrate ability to generate the Production Records.

- 55 canisters were filled.

o Each canister was sampled; most were destructively examined.

- Data comparisons/evaluations included:

o Glass sample durability results (measured by the PCT) from pour stream samples and from the canisters were compared to results for EA glass which indicated that acceptable glass products had been produced.

o Melter feed composition and predicted PCT results calculated from measured composition compared to actual glass results.

o Glass pour stream sample results compared to results from samples taken from canisters to confirm that sample was representative.

- Initiated and completed in 1995.

\section{Proficiency Runs - Transition to Radioactive Operations}

- Two batches of melter feed were produced.

- Maintained operator proficiencies during Operational Readiness Reviews.

During the Waste Qualification Runs, the feed was varied as discussed above to demonstrate the ability of the control strategy to handle the variability and to demonstrate the ability to produce an acceptable glass product by controlling the melter feed composition. Figure 5-1 highlights key features of the Waste Qualification Runs. The results of the qualification program are documented in WQR Volume 5, Technical Bases for DWPF Product Control Program [51], and data from the runs was included in several volumes of the WQRs.

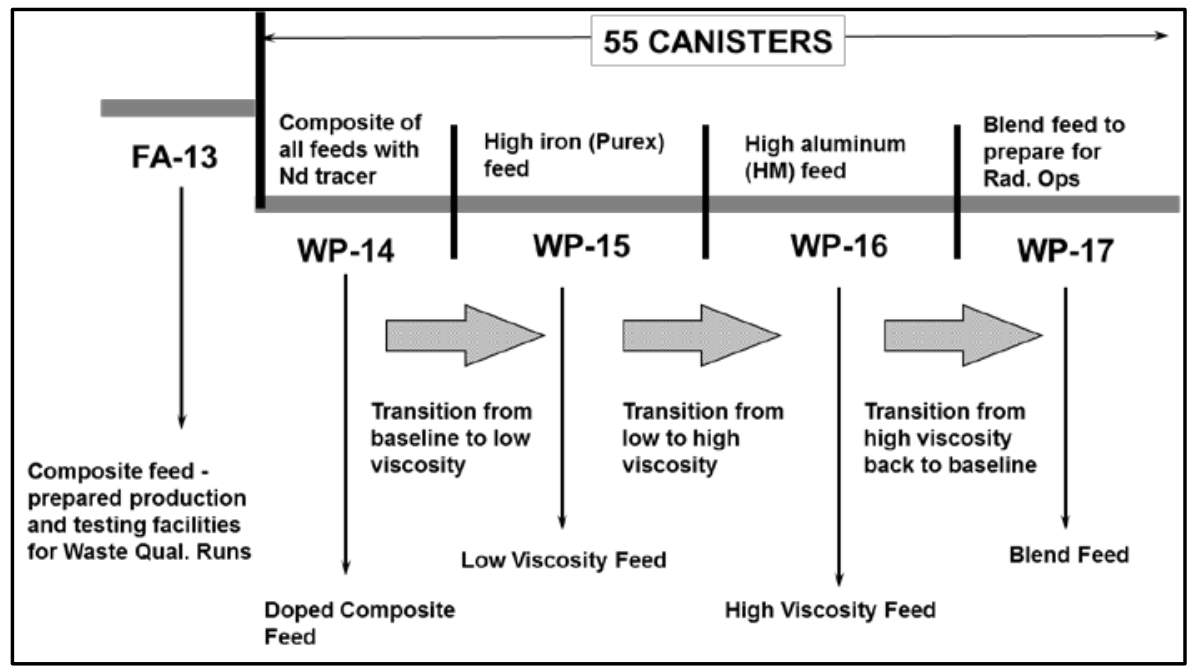

Figure 5-1. Waste Qualification Runs

While the discussion above focused mainly on the chemical processing and waste form aspects of the DWPF process, significant characterization was also performed on the canisters to ensure that they would consistently meet the requirements of the EM-WAPS. The results of these characterization analyses were the principal data that demonstrated the ability to comply with the EM-WAPS. [6] Documentation of the methods for compliance with the EM-WAPS canister related specifications can be found in WQR Volumes 8, 9, 10, 11, and 12. [55 - 59] 
In March 1996, DWPF was ready for radioactive operations and that month the first transfer of radioactive sludge was fed to DWPF from Tank 51. The first canister of Savannah River HLW glass was moved to the Glass Waste Storage Building (GWSB) in May 1996. Table 5-1 summarizes the timetable of the qualification program and DWPF operations from March 1996 to May 2013. The Qualification columns in this table refer to only the SRNL demonstrations of the DWPF processes with the radioactive qualification sample taken from Tank 51 (or Tank 40 for Sludge Batch 2) and the associated paperwork for DWPF acceptance; the other columns do not include the time-line for simulant studies performed to determine the parameters for the qualification nor the associated research and development to define and validate the glass composition space. These qualification activities with simulants and paper assessments start anywhere from 9 to 30 months ahead of time depending on the need date and complexity of the batch. The variance is influenced by the results of the studies and changes in planning for establishing the macro-batch. A quick review of this table reveals trends that have occurred in the DWPF:

$>$ The first few sludge batches produced more canisters than the later batches because of the smaller batch sizes. The batch size was reduced due to concerns over retained hydrogen generation in the waste tanks.

$>$ The curie content per canister shows a trend of processing more active sludge batches, and the co-processing with salt, which contains Cs.

$>$ Waste loading has varied with each batch. In most cases, types of sludges (HM or PUREX), feed behavior during processing, or low melt rate ultimately limited waste loading even though the projected operating windows would allow for higher targeted waste loadings. ${ }^{5}$ In other batches, the fissile content of the sludge limited waste loading to maintain fissile concentrations in glass below the $897 \mathrm{~g} / \mathrm{m}^{3}$ criteria. Glass properties (such as high or low $\eta, \mathrm{SO}_{4}$, and/or $\mathrm{T}_{\mathrm{L}}$ ) ultimately define the projected operating window for each sludge, but DWPF elects not to target the maximum waste loading allowable by the PCCS models as blending uncertainties in waste loading and composition must be considered $^{6}$.

\footnotetext{
${ }^{5}$ Melt rate decreases with increased WL, in the absence of forced convection. Therefore, to achieve maximum waste throughput, for some sludge batches, DWPF targeted WLs below the maximum operating window for the frit - sludge system being processed. The intermediate WL target is a compromise between melt rate and canister counts but is a strategy to maximize waste throughput and tank closure which ultimately dictates overall mission life.

${ }^{6}$ Testing and analysis has been performed to determine how accurately the DWPF laboratory can measure a key indicator of waste loading ( $\mathrm{Fe}, \mathrm{Li}$, or $\mathrm{Al}$ for example). These analyses showed that the laboratory hit the target $\pm 4 \%$. [12] If limit is for $\mathrm{Pu}$ or fissile, the laboratory factors in the $4 \%$ measurement uncertainty for this target. If it is contractual limit, the laboratory uses a running average for WL to hit the nominal target.
} 
Table 5-1. DWPF Sludge Batch Processing

\begin{tabular}{|c|c|c|c|c|c|c|c|c|c|}
\hline \multirow[t]{2}{*}{$\begin{array}{l}\text { Macro- } \\
\text { Batch }\end{array}$} & \multirow[t]{2}{*}{$\begin{array}{l}\text { Sludge } \\
\text { Batch }\end{array}$} & \multicolumn{2}{|c|}{ Qualification } & \multicolumn{2}{|c|}{$\begin{array}{c}\text { DWPF } \\
\text { Processing }\end{array}$} & \multirow[t]{2}{*}{$\begin{array}{l}\text { Canisters } \\
\text { Poured }\end{array}$} & \multirow[t]{2}{*}{$\begin{array}{c}\mathrm{Ci} \\
\text { Immob. }\end{array}$} & \multirow[t]{2}{*}{$\begin{array}{c}\mathrm{Ci} / \\
\text { Canister }\end{array}$} & \multirow{2}{*}{$\begin{array}{c}\text { Average } \\
\text { Waste } \\
\text { Loading } \\
\text { wt. \% }\end{array}$} \\
\hline & & $\begin{array}{l}\text { Start } \\
\text { Date }\end{array}$ & $\begin{array}{l}\text { Finish } \\
\text { Date }\end{array}$ & $\begin{array}{l}\text { Start } \\
\text { Date }\end{array}$ & $\begin{array}{l}\text { Finish } \\
\text { Date }\end{array}$ & & & & \\
\hline 1 & $1 \mathrm{a}$ & 9/1995 & $1 / 1996$ & $3 / 1996$ & 1999 & 495 & $4.01 E+05$ & $8.1 \mathrm{E}+02$ & 28 \\
\hline 2 & $1 \mathrm{~b}$ & $1 / 1998$ & $5 / 1998$ & 1999 & 2002 & 726 & $3.78 \mathrm{E}+06$ & $5.2 \mathrm{E}+03$ & 28 \\
\hline 3 & 2 & $8 / 2001$ & $2 / 2002$ & 2002 & 2004 & 363 & $2.52 \mathrm{E}+06$ & $6.9 \mathrm{E}+03$ & $28 / 34$ \\
\hline 4 & 3 & $6 / 2003$ & $3 / 2004$ & $3 / 2004$ & 2007 & 727 & $7.40 \mathrm{E}+06$ & $1.0 \mathrm{E}+04$ & 38 \\
\hline 5 & 4 & $1 / 2006$ & $12 / 2006$ & $5 / 2007$ & $11 / 2008$ & 314 & $3.19 \mathrm{E}+06$ & $1.0 \mathrm{E}+04$ & 33.3 \\
\hline 6 & $5 *$ & $3 / 2008$ & $9 / 2008$ & $11 / 2008$ & $6 / 2010$ & 323 & $1.38 \mathrm{E}+07$ & $4.3 \mathrm{E}+04$ & 30.7 \\
\hline 7 & 6 & $10 / 2009$ & $5 / 2010$ & $6 / 2010$ & $5 / 2011$ & 194 & $6.37 \mathrm{E}+06$ & $3.3 \mathrm{E}+04$ & 33 \\
\hline 8 & $7 \mathrm{a}$ & $9 / 2010$ & $3 / 2011$ & $5 / 2011$ & $12 / 2011$ & 197 & $4.86 \mathrm{E}+06$ & $2.5 \mathrm{E}+04$ & 36.5 \\
\hline 9 & $7 \mathrm{~b}$ & $3 / 2011$ & $8 / 2011$ & $12 / 2011$ & $5 / 2013$ & 325 & $7.68 \mathrm{E}+06$ & $2.9 \mathrm{E}+04$ & 38.3 \\
\hline 10 & $8 * *$ & $9 / 2012$ & $2 / 2013$ & $5 / 2013$ & & 78 & & & \\
\hline & & & & Total throu & U & 3650 & $5.00 \mathrm{E}+07$ & & \\
\hline
\end{tabular}

* Began sludge and salt coupled operations, ** SB8 is through the end of August 2013

\subsection{Facility or Operational Changes Impacting Sludge Batch Qualification}

During the development of the GPCP - Sludge Batch Qualification Program, assumptions on the baseline operating flowsheet and future operations had to be made. As the DOE and SRS missions have changed and funding constraints have been realized, the DWPF baseline and programs have been adjusted to accommodate the changes.

Initial DWPF operations targeted a nominal sludge loading of $28 \mathrm{wt} \%$ with canister production times greater than 24 hours per canister. Due to the high cost of monitoring the waste tanks and the potential for environmental release, the DOE challenged the site to accelerate the treatment of the HLW material. With respect to DWPF, mission acceleration could be accomplished by increasing the waste throughput or the amount of waste being processed per unit time. That is, by maximizing waste throughput, more waste is being processed per unit time; therefore, sludge transfers from the Tank Farm to DWPF occur more frequently which translates into faster mass removal of waste from the feed tank. To accomplish this, not only does one need to enhance or accelerate DWPF processing but other systems within the integrated flowsheet also need to support this approach. For example, if DWPF process acceleration results in emptying Tank 40 faster, upstream efforts in the Tank Farm to retrieve, blend, and wash the next batch, development of the CPC flowsheet, identification and receipt of the recommended frit, and all portions of the waste qualification effort at SRNL and DWPF are required to support this accelerated mission to avoid a feed break.

Simultaneously, qualification efforts at SRNL on the next sludge batch need to keep pace to ensure that the next sludge batch can be processed within DWPF without compromising process or product performance related issues. In short, acceleration of one facility's operation without the overall system being able to support that mission, could lead to DWPF feed breaks that defeat the intent of reducing the overall mission life. The reduction in overall mission life needs to be an integrated approach to ensure that upstream sludge preparation and qualification efforts can be met while downstream or supplemental facility operations (such as salt processing) can meet their 
goals as well. It is an integrated system and assuming acceleration in one facility leads to a net overall reduction in mission life can be misleading.

To meet this challenge, several initiatives were started to (a) develop alternative strategies to expedite waste qualification efforts, (b) develop alternative chemical and physical changes to support DWPF processing (e.g., CPC processing and melt rate), (c) develop alternative models or approaches to support increases in waste loading without compromising product quality or increasing the risks associated with melter processing, and (d) pursue sample cycle time improvement approaches. Although these initiatives commenced during sludge-only processing, development of the alternative strategies had to account for salt processing integration into the DWPF flowsheet.

With the incentives to improve waste throughput, there have been changes to sludge and salt preparation processes, physical and chemical changes to the DWPF process, and revisions and upgrades to the integrated set of PCCS models. These changes came about from challenges encountered during waste qualification, initial hot operations, efforts to improve the process, a need to increase processing rates to meet tank closure goals, and changes in waste characteristics between batches.

Below is a summary of changes that have been made that impact the attributes of the waste feed acceptance and/or qualification program as well as supported the enhancement to improve waste throughput in DWPF in order to reduce the overall mission life. Again, the operating baseline from which these changes were based or can be viewed was a nominal $28 \mathrm{wt} \%$ sludge waste loading, canister production times of $>24$ hours, and a nominal wash endpoint of $0.5 \mathrm{M} \mathrm{Na}^{+}$. More detail on process and equipment changes can be found in the presentations at the annual WM Symposium after years one and two of operation [34, 35, 36, 39], the overview of the SRS immobilization process given at the May 2009 Office of Waste Processing Technical Exchange [16], and in the 2012 report SRNL Phase 1 Assessment of the WTP Waste Qualification Program. [20]

Changes to the Tank Farm Extended Sludge Processing steps

- Sludge Composition

o Original estimates in the WCP assumed retrieval and blending scenarios that would ultimately target four nominal batch compositions.

o Current sludge batch preparations are based on regulatory commitments for emptying tanks and are constrained in batch size, so not as much blending is performed as originally envisioned.

- Aluminum Dissolution

o Initial sludge batch planning assumed aluminum dissolution would be implemented for most of the HM tanks during WCP projections.

o Instead, selective implementation of Al-dissolution has been used to reduce overall sludge mass volume when higher masses were projected after reconciliation of the sludge mass processed to date (e.g., Al-dissolution was performed during the preparation of Sludge Batch 5 and 6 - HM based sludges). These batches also experienced difficulty in settling during sludge preparation so Al-dissolution was performed to help mitigate this problem. Although Al-dissolution does reduce the amount of mass to be vitrified, there is a balance that must be maintained on how much $\mathrm{Al}_{2} \mathrm{O}_{3}$ to remove from the sludge batch. More specifically, criteria associated with minimum $\mathrm{Al}_{2} \mathrm{O}_{3}$ concentrations in glass exist in PCCS to ensure product durability. Therefore, the balance between how much $\mathrm{Al}_{2} \mathrm{O}_{3}$ to remove from the sludge batch to meet the $\mathrm{Al}_{2} \mathrm{O}_{3}$-based constraints in PCCS at a targeted WL interval must be 
monitored or $\mathrm{Al}_{2} \mathrm{O}_{3}$ additions to the frit will be required. The glass composition is only one component for consideration. The physical properties of the sludge may also require alteration through Al-dissolution. - Wash Target The strategy must look at the entire system to accurately assess the impact.

0 The wash endpoint is controlled by the sodium concentration in the supernate. The wash endpoint originally targeted $\sim 0.5 \mathrm{M} \mathrm{Na}^{+}$.

0 Wash endpoints now target between 1 to $1.5 \mathrm{M} \mathrm{Na}^{+}$, and there is analysis underway to consider increasing to $2.0 \mathrm{M}$ for some specific sludge batches. This change was originally necessitated by excess nuclear material released to the Tank Farms from the canyons ( $\mathrm{Pu}, \mathrm{Am} / \mathrm{Cm}, \mathrm{Np})$. Additional drivers include accelerated processing, water management, Tank Farm space limitations, and potential to control feed rheology better with an adjustable washing endpoint. The ability to tailor the frit to accommodate the washing endpoint, as well as blending in Tank 40, has enabled this change to be made.

o The incentive to improve waste throughput for DWPF also played a role in the dependence of the wash endpoint and the ability to tailor the frit to accommodate this change. During SB2 processing, a new frit (Frit 320) was developed to improve melt rate for a sludge washed to $0.5 \mathrm{M} \mathrm{Na}^{+}$. The compositional change to the new frit was to increase the total alkali $\left(\mathrm{Na}_{2} \mathrm{O}\right.$ in particular) which resulted in higher melt rates as well as the ability to target higher WLs (when coupled with a PCCS model change as will be discussed later) for SB2. This change supported the strategic shift in the washing strategy for future sludge batches. That is, given $\mathrm{Na}_{2} \mathrm{O}$ has in general a positive impact on melt rate and lowers liquidus temperature, having more $\mathrm{Na}_{2} \mathrm{O}$ in the sludge (through less washing) translates into more $\mathrm{Na}_{2} \mathrm{O}$ in sludge as WL increases. Thus future sludge batches shifted from the $0.5 \mathrm{M}$ $\mathrm{Na}^{+}$wash endpoint to a higher $\mathrm{Na}^{+}$molarity, which is "optimized" based on frit development efforts and CPC processing issues to ensure that there are operating windows for both DWPF targeted WLs and flowsheet processing (ensure rheological goals for sludge transfers and hydrogen generation constraints at key points in the DWPF process).

o Although transitioning toward less washed sludges has been beneficial to the Tank Farm system and certain DWPF operations, these must be balanced with other factors in which less washing could have negative impacts. Anion concentrations (in particular $\mathrm{SO}_{4}$ ) increase in the sludge as washing is reduced, which can ultimately limit targeted WLs. In addition, the higher anion content of less washed sludges can significantly impact the acid addition strategy for CPC processing as more formic acid is typically required which can lead to excessive hydrogen generation rates (in particular when coupled with high noble metals concentrations) in key DWPF unit operations. The facility offgas systems must be designed to handle this change. In DWPF, more gas is generated with higher acid addition levels and it has the potential to overwhelm the system.

0 The washing strategy must be a balanced approach among glass formulation goals, CPC processing objectives, and negating the potential negative impact of troublesome components that could ultimately limit WL and have negative impacts on CPC and/or melter processing. 
- Batch size

o Initial sludge batch planning was to create 1 million gallon batches that would provide adequate sludge to support multiple years of DWPF processing.

o One million gallon batches are no longer possible because of concerns of retained hydrogen when sludge solids accumulate more than 90 inches. Before this concern arose, the safety basis assumed 50\% retention of radiolytically generated hydrogen based on calculated hydrogen generation rates from the sludge composition. The quiescent time is calculated from this generation, and stirring of the tanks to release hydrogen is performed before the expiration of this time to mitigate the safety concern. When solids are higher than 90 inches, the system assumes 100\% retention, which reduces the quiescent time and interferes with required settling times during extended sludge processing.

o The smaller sludge batches require more frequent preparation and qualification of sludge batches which is discussed below.

- Preparation/Feed Tanks

o The initial planning was to use two tanks for preparing sludge batches (Tank 51 and 40). The prepared tank would directly feed DWPF to support day-today operations; while the second tank would be used to prepare the next sludge batch. Once heel volumes in the feed tank to DWPF reached a minimum level (40 inches minimum level to support pump operations), the Tank Farm transitioned to feeding DWPF from the second tank which initiated a new sludge batch.

o Due to accelerated mission objectives and the start of salt processing, the strategy for feeding and preparing tanks for processing had to change. Based on current operations, Tank 40 is the only feed tank to DWPF. While Tank 40 directly feeds DWPF, the next sludge batch is being prepared in Tank 51. This concept is consistent with the original qualification strategy. However, divergence now occurs when Tank 51 is needed for other bulk sludge transfers. At this point, the contents of Tank 51 (sludge batch) are transferred onto the heel of Tank 40 to constitute a new sludge batch. The Tank 40 heel volume can vary based on contractual obligations and/or the blending and washing strategy of Tank 51, which may require more or less of a Tank 40 heel to ensure product compliance and CPC operational requirements or constraints can be met.

o The change in tank preparation and feeding strategy also required a change in the qualification strategy and testing performed before acceptance of the sludge batch. During development of the DWPF WCP, it was recognized that a heel would always be present in Tank 40 and 51 because of the pump limitations but the goal was to transfer, prepare, and qualify additional sludge on that heel. Thus, the qualification sample would contain whatever heel remained in the tank. With the separation of these processes by tank, the qualification sample can no longer contain the heel. However, given the uncertainty of the potential heel volume that will be in Tank 40 upon transfer, DWPF adopted a strategy that took advantage of the demonstrated acceptability of the already being processed batch and the batch being qualified to demonstrate sludge batch acceptability. This "good + good" strategy was already being implemented in the DWPF from a glass composition perspective. However, there was recognition that actual processing would be of a different composition and testing was needed to 
confirm that the blended material would be acceptable. Therefore, the demonstrations performed with the qualification sample only include the material being prepared in Tank 51. This data is used by DWPF to demonstrate that the WAC for DWPF can be met for that sludge batch. Simulant flowsheet testing is then performed with the projected blend composition to provide the operating window for DWPF processing. While this data is not used in demonstrating compliance with the WAC, it is used by DWPF to set their processing parameters. This set of tests was not required when the sludge preparation and feed tanks were the same. The other change included the glass formulation studies since the composition of the heel must be considered in assessments of the glass and operational processing window. Frit assessments to determine the optimal frit composition and processing window use this composition. After the frit composition and potential window is generated, the glass variability study is performed to verify the acceptability of the product durability model. The material from Tank 51 cannot be transferred until the qualification studies with the radioactive sample and the flowsheet studies and glass formulation studies are completed that demonstrate that the material can be processed in DWPF. From a EM-WAPS reporting perspective, all analyses are performed on the material that is either fed to (i.e., Tank 40 after blending) or processed in (SME samples) DWPF so this change in qualification strategy did not change the macro-batch reporting requirements or sampling.

\section{Change to Salt Processing Strategy}

- The original salt process involved in-tank precipitation. During DWPF qualification, it was assumed that the in-tank precipitation process would be operational and allow for coupled processing of the salt and sludge streams.

- With the transition and implementation of the actinide removal and solvent extraction processes (ARP/MCU), adaptation of the DWPF flowsheet was required. The DWPF process changes have included increased boiling and caustic boiling of the sludge. The ARP addition during SRAT boiling increases cycle time, but not significantly. The MCU addition simply replaces time under reflux, so cycle time is minimally impacted. Overall, the CPC has accommodated these streams relatively easily. This challenge will be more problematic when the large volumes anticipated for SWPF begin to be processed. Understanding organic partitioning has been the major challenge to address with the introduction of the ARP/MCU streams.

- With respect to glass formulation issues, the actinide removal process ultimately resulted in a substantial compositional shift relative to the in-tank precipitation process. For the in-tank process, the assumed nominal contribution to waste loading was $8 \mathrm{wt} \%$ oxides and a different frit was to be used versus sludge only. With ARP/MCU, additions are not consistent and the frit must accommodate from no material to a full tank of material due to the close coupling of the facilities (i.e., very little lag storage for ARP or MCU). This can result in significant compositional swings within a sludge batch. Although these compositional transitions are planned for in advance (e.g., the variability study covers both sludge-only and coupled operations flowsheet), there has been a significant increase in the challenge to identify frits capable of handling both sludge-only and coupled operations for the large volumes needed for sprint operating capacity (that is, the ability to quickly process material accumulated before or after an outage) in the DWPF while providing access to WLs of interest. As will be discussed, this challenge has only been complicated by the transition to higher WLs. 
- With future salt processing, the potential for extremes in composition become more of a concern due to the anticipated increase in volume of salt to be processed.

WAC Related Changes

- One example is the sludge solids content target but others include the NOx emissions target, glass solubility limits, and corrosive species limit, which have all changed since start-up. New criteria have also been added such as organic carbon concentration and temperature because of the MCU/ARP processes. See section 7.2.7 for additional discussion on these changes.

- Rheology controls were originally just a solid loading limit - total solids.

- Experience has shown that more relevant criteria for controlling rheology are yield stress and consistency ${ }^{7}$. By staying within the limits, which were set from DWPF testing, the ability to ensure mixing and transfer of the material to and within DWPF are maintained. The DWPF receipt limit is set to maintain rheology controls in the facility, which is part of the GPCP.

\section{DWPF Process Changes}

- Frit Composition

0 As previously discussed, the original baseline flowsheet assumed a $28 \mathrm{wt} \%$ sludge waste loading with either a sludge-only or coupled operations (sludge loading of $28 \%$ and precipitate hydrolysis aqueous (PHA) of $8 \%$ ) flowsheet based on a wash endpoint of $0.5 \mathrm{M} \mathrm{Na}^{+}$. The baseline also assumed one frit for sludge-only processing and another for coupled operations.

o Given the flowsheet changes and the need to optimize throughput, the frit composition is tailored (i.e., composition is adjusted in the fabrication process for the batch, no changes to frit composition are performed in DWPF) to each sludge batch to account for or be robust to the presence or absence of the salt stream, potential changes in the salt stream volumes introduced into the SRAT, and the higher WL targets (as will be discussed below). The tailored frit must also provide a WL window of $\pm 4 \mathrm{WL}$ points around a nominal target WL to account for uncertainties in the DWPF blending and analytical processes. With higher volumes of salt to be processed through DWPF, the challenge will be to develop strategies to dampen out significant compositional swings assuming both sludge-only and coupled operations flowsheets are still required for each sludge-batch.

Faster Sample Analytical Methods

- Analysis of the SRAT receipt, SRAT product and SME product are critical steps in the DWPF flowsheet to either demonstrate process or product performance limits have been met. Although critical with respect to supporting blending and SME acceptability decisions, these analyses can be time consuming and have the potential to become the rate limiting step in the process. That is, SRAT processing (to produce the SRAT product) may be held up waiting on analysis from the SRAT receipt and transfers to the SME or MFT may be held up waiting for analyses.

- Improvement or changes to analytical methods to reduce the time to proceed to the next step have included [15]:

\footnotetext{
${ }^{7}$ DWPF and SRNL have used "consistency" in place of "plastic viscosity" for the Bingham Plastic model used to regress rheological property data.
} 
o Changing from Hydragard to Isolok samplers for the SRAT and SME processes to reduce downtime and allow greater flexibility in sample size taken in addition to reducing the amount of flushing required. The new samplers were extensively tested with simulants to ensure that they were functionally equivalent to the Hydragard samplers prior to installation.

o Revision of analytical methods to reduce digestion time. New sample preparation protocols have been implemented and are under further consideration to take advantage of the flexible sample size of the Isolok sample.

- Batch Calculation and Acceptance Strategy Protocols

o Sample and send protocols for SRAT products after the first ten SRAT runs in a batch. Once acceptable processing has been shown for a sludge batch, DWPF does not delay the transfer of SRAT material to the SME tank. The frit addition calculation is not performed until the sample is analyzed. This allows new feed to be processed from Tank 40 and SRAT processing to start.

o After the first ten batches are completed, the SRAT acid calculation is performed prior to receiving results for metal and mercury content. A material balance is performed based on previous results and the solids content of the SRAT receipt.

Elimination of MFT Sampling:

- The MFT was originally sampled as part of the reporting program at DWPF.

- A study of analytical results from the SME and MFT for Macrobatches 1 and 2 showed that the data taken from the MFT was essentially redundant to the data from the SME, and as a result added no further information. For the Production Records, chemical composition of feed to the melter is now based on analysis of the material in the SME, and the radionuclide inventory based on sludge analysis and "dilution" using chemical composition.

Waste Loading

- Baseline sludge waste loadings were $28 \%$ at startup.

- Development and implementation of new glass property models (e.g., a $T_{L}$ model) and an alternative approach for defining acceptance limits for durability coupled with strategic frit development efforts have resulted in significant increases in waste loading relative to the baseline. Since implementation of these alternative approaches, targeted WLs have reached up to $38 \%$. The optimal waste loading for processing has changed with each sludge batch and sometimes depends on the amount of excess nuclear material added to the sludge batch with the fissile limits at $897 \mathrm{~g} / \mathrm{m}^{3}$. [42]

\section{Salt Deposits on Canister Surfaces}

- During the qualification runs, white and yellow salts were found on the top head of the canisters above the glass line. These salts consisted of sodium, chloride, fluoride, and sulfate and were believed to have volatilized from the glass during cooling. Glass solubility limits and canister corrosion limits were re-examined after these deposits were found but no limit changes were made.

Crystals and Voids in Poured Canisters

- Upon sectioning of the canister during qualification runs, both crystals and large voids were found in the glass of a couple canisters. The crystals found were predominantly spinel/trevorite but some acmite was also found. Each canister that was sectioned as well as any obvious crystals were sampled and subjected to 
durability testing. Since the crystal phases were consistent with those already identified and no impact on the glass durability performance was seen, no changes were made to the GPCP. The presence was noted in the WQRs. The glass voids were likely the result of pour interruptions or changes in the pour stream during filling of the canister. The main concern with the voids was that the can might be over-filled if only weight was used as a control for filling. Since the DWPF also had a level detection system, this anomaly could be handled in processing as demonstrated during qualification runs.

Initiatives to Accelerate Closure

- To accelerate closure of waste tanks, the DWPF melt rate/melter throughput was increased, and waste loading was increased to make fewer DWPF canisters. Melt rate/melter throughput improvements were accomplished through tailoring of the frit composition and sludge properties (washing endpoint changes), and physical changes to the melter (glass pump and then bubblers).

- Waste loading was increased through both the tailoring of the frit, implementation of new process control models, development of alternative approaches to various property constraints, and strategic planning associated with the sludge washing endpoint. These changes have resulted in a significant reduction in the total canisters to be produced at DWPF and, perhaps more importantly, a significant reduction in the overall mission life of the Tank Farm and DWPF which translates into a tremendous cost savings for the DOE.

A couple of key observations from these changes relative to the establishment and maintenance of a GPCP are:

1. Improvements in the understanding of the feed preparation chemistry and glass product models will allow changes to be made to the process to reduce conservatism. Each tank or sludge batch has presented a unique challenge to DWPF processing.

2. The ability to adjust the process variables and remaining flexible during startup are important for establishing and maintaining a strong GPCP. As discussed in this report, the initial baseline processing strategy has evolved from a $0.5 \mathrm{M}$ washed sludge being processed at $28 \% \mathrm{WL}$ with a "fixed" frit to a $1-2 \mathrm{M}$ washed sludge being processed up to $38 \% \mathrm{WL}$ with a tailored frit. Although these enhancements required changes in certain strategies, the underlining technical basis for qualification, waste compliance, product control, and waste form acceptance were flexible enough to allow these changes without compromising processing, product quality, or reporting requirements.

\subsection{Facility Changes}

For the SRS Tank Waste System, processing challenges have routinely occurred, and will continue to occur, that require knowledgeable personnel, resources, and time to resolve. There are many variables in the process that influence whether operations and glass production will be successful. Since DWPF startup, significant challenges occurred at SRS in all unit operations from Tank Farm retrieval of sludge to DWPF pretreatment and melter operations, to handling the recycle streams from the DWPF process.

The types of challenges faced by the facility changed as the operation progressed through different operational regimes (startup testing, initial operation, and process rate improvement initiatives). Although many of the issues described below are specific to the SRS process, a description of these issues is provided to allow an understanding of the breadth of the issues faced 
during startup, initial operation, and attempts at optimization and acceleration of the process. These issues listed below are typically operational in nature and did not impact qualification programs or strategies unless specifically noted.

\subsection{Tank Farm Operation}

Challenges during sludge retrieval and batch preparation in the Tank Farm have resulted from discovery of conditions not expected in the waste tanks such as a burkeite crust in Tank 4, mixing pump degradation and failures, changes in sludge batch planning to accommodate additions of excess nuclear material, as well as tank space constraints for handling the large volumes of wash solutions generated by in-tank sludge washing. Tank Farm operations also include the monitoring and maintenance of tank chemistry which is accomplished through a corrosion control program.

\subsubsection{Waste Tank discoveries}

Tank 8

During retrieval of Tank 8, it was noted that the sludge in the tank had dried and hardened. Supernate was added to the tanks and the slurry mixing pumps were operated above the sludge to loosen the sludge layer. Over time, the slurry mix pumps were gradually lowered to loosen and retrieve the tank. While the strategy of gradually lowering the pumps into the sludge layer is typical of sludge retrieval, this process took longer for Tank 8 due to the hardened sludge. At the time, the Tank Farm had enough time that no changes in the sludge batch were necessary to meet the schedule for Sludge Batch 2 readiness. However, reductions in the size of each sludge batch and the increases in the process rates at DWPF have resulted in accelerated schedules that could not have been met by the retrieval process in Tank 8 .

Tank 4

During initial efforts to lower the submersible mixing pumps into Tank 4, a hardened crust was noted on top of the sludge layer. Samples revealed that this crust was nearly pure burkeite, a sulfur compound that had precipitated from the supernate. The crust required additional supernate to be added to the tank to dissolve the burkeite layer prior to sludge retrieval. The difficulty in retrieving the tank led to changes in the sludge batch plan that removed Tank 4 from SB4 and the amount of sulfur (and nickel) in the tank limited the amount of Tank 4 that was included in SB5.

\subsubsection{Mixing Pump Degradation and Failures}

The transfer and mixing pumps used in the Tank Farm have water cooled bearings. A constant pressure of water is maintained on the bearings and a small amount of the water leaks into the tank. As the pumps degrade, the leak rate of water from the pumps increases. Operating strategies have been changed to accommodate the amount of "bearing water" that leaked into the DWPF feed tank from operation of the mixing pumps that included operation of three instead of four mixing pumps on a periodic basis, concentration of receipt by boiling in DWPF, and decanting excessive supernate from the qualified feed.

\subsubsection{Excess Nuclear Material}

The SRS has a number of excess nuclear materials streams in the separations process. The final disposition path for some of these streams has been to transfer the material to DWPF for vitrification by adding the material to the sludge during sludge batch preparation. Excess americium, curium, neptunium, and plutonium have been disposed in this manner. Incorporation of these streams has led to changes in sludge batch washing, DWPF feeding protocols, as well as requiring careful planning to avoid exceeding the repository fissile limits for the glass produced by DWPF. As an example, the SRR has a desire to mitigate soluble Np being transferred 
throughout the Tank Farm and ending up in Saltstone. Therefore, the Np can only be sent to Tank 40 where washing is not performed or where decants can be controlled.

\subsubsection{Space Constraints}

The sludge batch preparation process generates large volumes of dilute waste supernate and the DWPF generates approximately 5 gallons of recycle for each gallon of sludge vitrified. The amount of available tank space is always a challenge for Tank Farm operations and acceleration of DWPF processing rates has strained the Tank Farm evaporation system to keep enough tank space open to continue processing. Efforts to reduce the amount of DWPF recycle are discussed below. Efforts to reduce the amount of dilute supernate from the sludge washing process have primarily focused on reuse of supernates in the washing process whenever possible.

\subsection{DWPF CPC Operation}

The CPC pretreatment process at DWPF experienced issues during the Startup Test Program and initial operations such as level instrumentation failures, changes to the acid strategy, excessive foaming during pretreatment, gas chromatograph system flow issues, abrasion of DWPF process equipment by the frit, managing $\mathrm{H}_{2}$ generation, controlling rheology, impact of alternative waste materials (coal, zeolite, sand, etc), excessive process pump trips from air entrainment, difficulty meeting melter flammability constraints on organic carbon, offgas fouling from mercury deposits, and SME coil fouling.

\subsubsection{Level Instrumentation Failures}

DWPF initially planned to use a simple bubbler for level measurements, but excessive amounts of plugging were noted during startup testing. The bubblers were replaced with Holledge Diaphragm Probes. The Holledge probes proved unreliable for the SME due to the high solids content combined with operation at boiling temperatures. A large diameter bubbler (3.4 inch ID) was selected to replace the SME level probe after extensive testing with simulants. The accumulation of solids in the larger diameter probe took longer than in the small diameter bubbler probes initially used and the probes could be cleared with high pressure air. The larger diameter probes were installed in the SME after commencement of radioactive operations. [3]

\subsubsection{Chemical Process Acid Strategy}

For the DWPF, acid addition is performed to prepare the waste for feeding to the melter. The strategy must destroy nitrite, neutralize carbonate and hydroxide, and reduce manganese and mercury. The process is also used to adjust melter feed rheology while maintaining the generated hydrogen from the reaction of formic acid with noble metals to below $25 \%$ of the lower flammability limit. Nitric and formic acids are added to target and maintain a glass redox balance to avoid foam formation and metal precipitation in the melt pool. Initially, formate was expected to be present in the salt streams, but technical issues with the salt process required startup of DWPF with a sludge only flowsheet. A flowsheet was developed to use a formic acid addition to provide the reducing agent eliminated by removal of the salt waste streams. This acid addition was adjusted to include nitric acid as well to better control REDOX. A REDOX model was developed and implemented to allow calculation of the correct blend of formic and nitric acids for processing. This model must take into account the oxidizing species present in the sludge, the amount of each acid to be added, and expected reactions during processing.

Updates to the REDOX model have been performed as more information is learned about SRAT/SME process reactions and as processing changes have occurred that added new components (oxalate from sludge, coal in sludge, solvent from salt processing) or the amounts of 
selected components increased (antifoam added in processing, manganese concentration in sludge).

With the shift in sludge retrieval, blending and washing strategy, SRNL has been able to accommodate these upstream flowsheet changes through strategic flowsheet development work. Although the current acid addition strategy still relies on the use of nitric and formic acid, implementation of a glycolic acid based acid addition strategy is being evaluated, which will reduce the hydrogen generation issues while maintaining REDOX and rheology requirements as well as other CPC processing goals.

\subsubsection{Foaming}

Excessive foaming occurs during concentration of the sludge by boiling and during acid additions. The foaming is the result of small particle stabilization of the foam lamella versus classical foam stabilization by surfactants. A commercial antifoam agent (Dow 544) had been selected to mitigate the foaming, but it was quickly degraded by the mercury in the process. A proprietary antifoam (IIT-747) was developed specifically for the DWPF process by SRNL and researchers at the Illinois Institute of Technology. [5] This antifoam performed well, but still requires frequent addition to the process and is rapidly degraded by high or low $\mathrm{pH}$ conditions. Increased mercury concentrations as well as lower than design basis boil-up rates in recent batches have extended the amount of time at boiling, leading to increased antifoam use and difficulty meeting the melter flammability constraints for organic compounds based on the current control strategy. Attempts to balance the antifoam and melter flammability constraints have led to more frequent foam overs during CPC processing. The mercury concentration limit in the SRAT product was increased to reduce the mercury steam stripping duration by taking credit for SME boiling for mercury stripping, but mercury is still problematic.

\subsubsection{Gas Chromatograph System Flow Issues}

A gas chromatograph system is used to monitor hydrogen generation during CPC processing. This system has a pretreatment system to remove excess moisture and prevent particulate from reaching the instrument. Low flow, presumably from high delta pressure across the pretreatment system, occurs during acid addition to the SRAT process as copious amounts of carbon dioxide and nitric oxide gases are emitted from the reactions. These flow issues led to a reduction in acid addition rates during formic acid addition and extended processing cycle times. Upgrades to the gas chromatograph system have contributed to a reduced SRAT cycle time via a decreased failure rate of the gas chromatographs, and it has contributed to a better understanding of SRAT chemistry through the additional monitoring of SRAT offgas components. [15]

\subsubsection{DWPF Equipment Abrasion}

During startup testing, excessive wear was noted in the SME vessel agitator, heating coil, and pump systems due to the highly abrasive nature of the process frit and the high agitator speeds required to maintain tank homogeneity and high pump rates needed to maintain the frit in suspension in transfer lines. Specialized materials were used to mitigate the abrasion and extend equipment life. Minimal problems have been encountered since then under normal operating conditions. [4, 34]

\subsubsection{Hydrogen Generation}

The "acid addition window" for the DWPF CPC process is defined by the amount of acid required to completely destroy nitrite on the low end and the amount of acid that results in excessive hydrogen generation on the high end. Initial sludge batches were washed to approximately $0.5 \mathrm{M}$ sodium in the supernate and these sludges generally contained low levels of 
noble metals (hydrogen generation is primarily from noble metal catalysis of formic acid) and the resulting acid addition windows were very large. As the washing protocol has shifted to less washed sludges and noble metals have increased, the amount of acid required to ensure nitrite destruction has increased significantly. In addition, higher levels of noble metals have decreased the amount of excess formic acid that can be tolerated. The resulting reduction in acid window size has been carefully managed, but the constraints imposed by the acid window have reduced the flexibility to mitigate other processing issues such as high yield stress, melter flammability issues, or REDOX control through changes in acid addition strategy.

\subsubsection{Rheological Property Control}

The rheological properties of slurries are dependent on many factors: composition, particle size/morphology, $\mathrm{pH}$, and processing history. Control of the rheological properties of the melter feed, particularly yield stress, is needed to ensure that process slurries can be sampled and pumped with existing equipment while also maintaining the frit particles in suspension. Issues with highly viscous feed were noted during selected sludge batches. During SB2, process transfers were performed at elevated temperature as the feed was too viscous to pump at lower temperatures. Eventually, SB3 was transferred on top of SB2 well before the minimum level was reached in Tank 40 to help mitigate the processing issues with SB2. Studies with simulants indicated that wash endpoint had a significant impact on melter feed rheology for this batch as well as other batches.

Control of rheological properties is performed through acid addition strategy, adjustments to the wash endpoint, and total solids targets. As sludge batches have become less washed, the amount of adjustment possible through acid addition changes has decreased. In addition, as waste loading increases the resulting melter feed slurry becomes more viscous. These changes have required the solids target for melter feed to be lowered from $50 \%$ total solids to approximately $43 \%$ total solids. The adjustment of the solids target for the melter must be balanced with target melt rate, as the solids target is decreased there is a negative impact on the melt rate.

\subsubsection{Air Entrainment}

The high speed agitation in the DWPF process tanks can lead to entrainment of air at some tank levels. Highly viscous feed can preclude the entrained air from escaping from the slurry, leading to issues with the process pumps becoming air locked and tripping. This was experienced in SB2. Control of the rheological properties to mitigate this issue has resulted in lower melter feed concentrations. [10, 34]

\subsubsection{Coil Fouling}

The process tanks at DWPF are heated by tightly wound steam coils. Fouling of these coils, presumably due to low velocities near the coils as a result of excessive yield stress, was noted during SB2 and recent sludge batches. During SB2, the coils would return to typical operation once the slurry was diluted but recent fouling events have been irreversible and has required removal of the coil followed by cleaning with a water jet. Control of the rheological properties to mitigate this issue has resulted in lower melter feed concentrations. Efforts are currently in progress to resolve this issue.

\subsubsection{Mercury Buildup in Vent System}

Mercury oxide in the sludge is reduced to elemental mercury and steam stripped during DWPF CPC processing. The design basis for DWPF was for mercury to be reduced, stripped, and captured in the mercury water wash tank. Recent batches have not been successful in capturing the mercury in the wash tank. Additionally, issues with buildup of mercury in the vent system 
have required several cleanouts of the system. The mercury collection system for DWPF is not functioning as designed and efforts are in progress to resolve this issue. [19]

\subsubsection{Melter Offgas Flammability Constraints}

Organic species form volatile species when added to the DWPF melter. These volatile species do not have sufficient reaction time in the high temperature melter to be completely reacted before being quenched in the offgas system. Calculations and models are used to determine the amount of organic carbon that can be fed to melter without causing flammable gases in the offgas to exceed processing limits. The additional antifoam required by extending processing times and operations at high $\mathrm{pH}$, as well as increased sensitivity to sample analysis uncertainty as the acid

addition amounts increase due to less washed sludge, have led to difficulty meeting the melter flammability constraints and remediation of some SME batches has been required. Efforts are currently in progress to resolve this issue.

\subsubsection{Unusual Waste Species}

Selected sludge batches have contained components such as coal, sand, zeolite or oxalate above the concentrations previously considered. Additional testing was required during the sludge batch qualification process to evaluate these species and adjust processing accordingly. Identification of these species early in the sludge batch planning process allowed sufficient time to evaluate the impacts of the species during qualification efforts.

\subsection{Melter Operation}

DWPF melter operations have experienced melter pour spout clogging, increased waste loading and changes to glass models, offgas system fouling, excessive feed loop tripping, and implementation of forced convection in the melter.

\subsubsection{Melter Pour Spout Clogging}

During initial DWPF operation, degradation of the melter pour spout allowed the pour stream to wick onto the side walls of the pour spout and form a clog. Considerable effort was required to clean out the glass from the pour spout and resume operations. Investigation revealed that the pour spout "knife edge" designed to allow clean disengagement of the glass stream was worn. An insert was developed and installed to restore a knife edge to allow disengagement. This insert is replaced at a regular frequency to maintain an acceptable knife edge. [7, 39]

In addition to the insert, additional heating was applied to the pour spout by installation of a heated bellows liner in place of the unheated system. This heated liner, along with the pour spout insert, has significantly reduced issues with glass clogging the pour spout.

\subsubsection{Increased Waste Loading Target and Glass Model Improvements}

DWPF operations has transitioned from a nominal $28 \%$ sludge oxide loading target up to $38 \%$ waste loading for certain sludge batches. Development and implementation of new glass property models (e.g., a new $\mathrm{T}_{\mathrm{L}}$ model) and an alternative approach for defining acceptance limits for durability [11] coupled with strategic frit development efforts served as the basis for this continuous improvement. The challenge is to monitor future operations (i.e., blending and retrieval strategies that will ultimately define a sludge batch) to identify "troublesome" components that require model revisions or upgrades to ensure DWPF can meet contractual obligations. Developing new models or revising current models is time consuming especially if gaps (no data) exist in the anticipated compositional region to be processed. 


\subsubsection{Implementation of Forced Convection in the Melter}

The baseline melter design relied on thermal convection within the melt pool to aid in the melting process of the incoming slurry melter feed. The conversion of the incoming feed to a glass product defines melt rate. The higher the melt rate, the faster melter feed can be fed to the melter and canisters can be filled with glass. Therefore, any physical or chemical changes that could be made to improve melt rate ultimately play a significant role in defining waste throughput for DWPF.

The glass pump designed by SRNL was implemented into Melter \#2 during processing of SB3. The glass pump was designed to "pump" hot glass onto the surface of the unreacted feed (or cold cap) to enhance heat transfer and aid in converting the melter feed into a glass product - or melt rate. The concept was to introduce forced convection to the glass and not rely solely on thermal convection. The glass pump was effective as melt rate increased by about $5-10 \%$. [9] Although the glass pump was effective, SRR and its partner EnergySolutions, designed glass bubbler tubes for implementation into a pre-existing melter design. Bubblers were implemented into Melter \#2 (September 2010) with the transition to processing of SB7a, and have consistently provided a positive impact on melt rate. During baseline operations, canister fill times could exceed 24 hours, with the implementation of the bubbler technology, canister fill times have been as low as 15 hours during SB8 processing. Melt rate is highly dependent on several factors including feed rate and $\mathrm{wt} \%$ solids, which can vary from sludge batch to sludge batch, thus direct comparisons of melt rate need to be made with some caution. Also, forced convection can lead to increased carryover into the offgas system which increases the frequency of offgas system cleanouts and more feed material in the recycle streams.

\subsubsection{Offgas System Fouling}

Fouling of offgas components was infrequent during initial operations. However, some of the efforts to reduce the amount of recycle generated resulted in more particulate reaching the high efficiency mist evaporator system and more frequent change out. Some of the recycle water mitigation efforts were rolled back as a result to balance recycle generation reduction with offgas fouling issues. As mentioned above, acceleration of melter feed rates through forced convection have increased melter offgas fouling both through the increased amount of feed throughput and through more vigorous cold cap behavior. To date, cleaning of the offgas system has not limited overall throughput.

\subsubsection{Feed loop trips}

The feed loop to the melter contains a flow meter and flush system. This flush system is designed to prevent plugging the line from settled solids or from drying out portions of the line near the melter. The flush automatically activates when the feed is stopped or when a low flow condition is detected. Excessive feed loop trips not only stop melter feed until the pump can be restarted, but also add a significant amount of dilution water to the feed from the flush and the pump prime water required to restart the pump. Initial relief was gained through fine tuning of the control system for the pump and the alarm setpoints. However, feed loop trips have increased during recent batches, efforts are underway to mitigate this issue.

\subsection{Recycle Handling}

DWPF generates approximately five gallons of dilute recycle for every gallon of waste feed treated. Extensive efforts have been made to reduce the volume of this recycle stream as well as to accommodate the recycle stream in the Tank Farm. Issues have been noted with silica in the recycle stream forming crystalline species in the Tank Farm evaporators and Tank Farm space constraints have to be managed carefully to ensure adequate tank space is available to receive the 
recycle stream. One of the three site evaporators has been dedicated to DWPF recycle to minimize formation of the alumino-silicates in all of the evaporators. Efforts to reduce the amount of DWPF recycle have been evaluated and some have been implemented.

\subsubsection{Silicon Impacts on Tank Farm Evaporation}

Formation of sodium alumino-silicates on the heated surfaces of the Tank Farm evaporator was traced to the amount of silicon in the DWPF recycle stream being sent to the Tank Farm. The processing strategies for evaporation of the DWPF recycle stream were reduced by this discovery and currently only one Tank Farm evaporator is authorized to perform evaporation of this stream. Additional controls have been placed on that evaporator to minimize the amount of scale formed.

\subsubsection{Tank Farm Space Constraints / Recycle Reduction Efforts}

Extensive efforts to reduce the amount of DWPF recycle due to space constraints in the Tank Farm have been conducted at DWPF. These efforts have been successful in some areas, such as the decontamination cell, but had to be rolled back in others, such as the elimination of steam flow to the Steam Atomized Scrubber units. DWPF continues to evaluate the process to reduce the amount of recycle and continues to update strategies to balance the desire for recycle reduction with the facility requirements for processing effectively.

\subsection{Lessons Learned and Future Changes}

The experiences gained from initial process development and qualification, and years of operations, have provided many lessons learned associated with HLW glass waste form production and qualification. These experiences also have set the stage for changes to be considered for the future.

During the May 2013 meeting between SRS and Hanford personnel to discuss Waste Feed Qualification, the SRR management team and SRNL pointed out four key attributes to consider when putting together and operating the program: the process must get the material from storage to the treatment process, safety basis margins must be understood and maintained, changes must be evaluated for impacts on other parts of the process, and at the end of a batch/run a feedback review to gather lessons learned must be conducted.

\subsection{Initial Qualification Lessons Learned}

The lessons learned from the initial qualification program were discussed at the May 2013 meeting [26, 27], in earlier sections of this document, and can be extracted from the other references. Below is summary of lessons learned during initial qualification.

> The program for initial qualification and startup is long and arduous. As discussed in Section 2.0, selection of the waste form started in the 1970s, glass as the waste form was selected in the 1980s, construction of DWPF was completed in the early 1990s and radioactive operations began in 1996. The DWPF product control program, including its technical basis, took many years to develop and to gain approval. Once DWPF began simulant operations, new processing issues were identified (e.g. foaming in the melter requiring adjustment of redox control) and facility modifications were required (e.g. materials changes because of wear from frit).

An objective should be to minimize the level of specifics in waste qualification documentation. The documentation of the program needs to be robust and technically sound, but it also must allow flexibility for future changes. Include strategies for changes 
(including elimination or minimization of various testing programs or analyses) based on operational experience.

It is critical to establish a broad envelope for product/process control and associated elements. This should include models and implementation methods, and the determination of uncertainties. It is also critical to recognize upstream process changes or introduction of secondary streams that may move the compositional regions for future operations outside of the compositional envelope that was initially envisioned.

Plan for wide variations in sludge/waste composition as there are uncertainties with knowledge of material in storage, tank retrieval and blending strategies, and new streams may be added. In addition, some streams will be intermittent - salt streams are not always included in DWPF SRAT batches (a corollary for Hanford would be the recycle stream). The plan should consider changes in flowrates based on processing considerations to support a "sprint" or to stop some process flows.

> The qualification program should include a well-developed and executed system that addresses:

- Acceptance criteria; which differentiate limits and targets.

- Planning of waste retrieval strategies, projection of waste feed compositions, and development of compliance strategies and formalized compliance plans by the sender.

- A formalized process for acceptance including sample analysis and testing.

\subsection{Operation Lessons Learned}

The lessons learned from the many years of operating experience were discussed at the May 2013 meeting [26, 28], in earlier sections of this document, in the 2012 SRNL assessment of the WTP waste qualification program [20], and in many of the references in sections 9.1 and 9.3. Below is summary of lessons learned from the many years of operating experience.

It is important to characterize the waste composition early during the qualification process to capture new reportable elements, identify species that may impact melter offgas flammability, and to understand the ability to process in DWPF.

$>$ As operating experience is gained, that experience should be used to reassess the bases for the Limits and Targets in the waste acceptance criteria. SRS has been able to use this experience to have positive impacts on waste loading and glass fill height, canister production rates, sulfate concentration to enhance corrosion control and improve glass solubility, and sludge washing strategies with Tank 51. Changes in the washing strategies had a positive impact on the Tank Farm since it allowed less wash water volume to be created for subsequent storage and treatment.

$>$ Maintaining core R\&D funds and resources by continued funding of qualification and process improvement programs has allowed DWPF to accommodate unknowns and to aggressively pursue opportunities. Continuing R\&D efforts in glass composition and waste treatment will enable improvements to the process such as improved processing time and efficiency, improved waste loading, and maintenance of the ability to respond to challenges over the long lifecycle of the program.

It is critical to not only focus on current or near-term operational goals, but to also align longer-term mission goals with current systems to identify any compositional and infrastructure gaps or needs. 
- DWPF is currently accepting salt from the ARP, but future flowsheet changes within that facility or startup of future auxiliary facilities (e.g., SWPF) may yield or introduce new "troublesome" components for DWPF processing. The increased volumes from SWPF processing are expected to increase the concentration of $\mathrm{Ti}, \mathrm{Nb}$, and/or $\mathrm{Na}$ for coupled operations flowsheets. Before the increased volumes are processed, an assessment of PCCS model applicability (development and/or validation ranges) will be necessary. If compositional gaps are identified early enough, R\&D efforts can be developed to generate new data, and to revise the models to support processing expectations once these streams are integrated into the flowsheet. If this R\&D is not completed, the model development and/or validation ranges may restrict WLs targeted by DWPF or the volume of a specific stream that can be transferred to the SRAT. These restrictions could negatively impact facility operations and the ability to meet goals for closing tanks.

$>$ The impact of one change on other parts of the process must be fully understood. Some negative impacts believed to be associated with aluminum dissolution were discovered in processing and included sludge with a higher yield stress, more adhesiveness and an affinity for foaming during SRAT processing. Another unintended consequence was longer SRAT processing times because of the higher concentration of mercury in the slurry (requiring longer process stripping times) and potentially lower melter throughput rates (waste loading was limited to $34 \%$ for the first aluminum dissolved batch). These processing issues had to be accommodated by the plant during processing. When processing issues are identified late in the flowsheet, the options to improve processing are limited because the batch has already been prepared and qualified.

Plan for challenges in tank retrieval and the batch preparation:

- Tank 8 was completely dried out and required extensive efforts to re-suspend the sludge.

- Tank 4 had higher than expected levels of sulfur and a layer of burkeite $\left(\mathrm{Na}_{6}\left(\mathrm{CO}_{3}\right)\left(\mathrm{SO}_{4}\right)_{2}\right)$ which required remediation. Remediation was by dissolution with inhibited water followed by an increased number of wash cycles.

- Smaller batches and faster processing at DWPF have required more frequent adjustment of planned sludge batches as any Tank Farm operational delays resulted in removal of the tank contents from the sludge batch.

Plan for challenges in final batch preparation and melter operation:

- Select sludge batches have been viscous and difficult to pump. Higher than typical temperatures were used during transfers as a mitigation technique, and solids targets were lowered.

- Extended processing times to remove mercury were noted in recent batches.

- Antifoam additions during extended processing challenge the ability to meet melter flammability constraints. 
Remotability has been critical to successful startup, initial operation and processing improvement initiatives for DWPF. As described above, nearly every unit operation at DWPF has undergone extensive troubleshooting, maintenance, or upgrades that were only possible because the facility was designed for remotely performing these actions. It is nearly impossible to predict in advance what processing issues will be faced through the life of a facility such as DWPF, remotability has allowed the DWPF to be flexible in response to changing conditions. Examples include, but are not limited to:

- Pour spout configuration changes to eliminate wicking.

- Changes in level instrumentation to mitigate bubbler plugging.

- Updates to melter to include bubblers to increase throughput.

- Changes to SME coils to minimize erosion.

- Cleanout of offgas system components to remove mercury deposits.

\subsection{Considerations for Future Changes}

Based on experience gained from 17 years of DWPF production and the potential changes in the final repository there are several future changes that should be considered. [20, 41]

Review existing DOE requirements documents (WA-SRD and EM-WAPS) and Producer (i.e., DWPF or WTP) compliance strategy documents to recommend changes based on DOE looking at alternative approaches for disposition of HLW and to consider the many years of radioactive operational experience that the United States now has.

- Imposed DOE requirements: Yucca Mountain fissile limit and RW-0333P quality assurance requirements.

- Potential compliance strategy changes to be initiated by Producers and submitted to DOE for concurrence include glass durability model compliance changes, sludge batch qualification demonstration reductions, and use of High Capacity Canisters to allow more glass to be disposed per can.

Use of the experience gained from years of DWPF operations to establish changes to requirements and compliance strategy.

- Reevaluating the uncertainties associated with glass models to allow higher waste loadings. Currently, the DWPF glass PCT performance is well below the EA glass limit (normalized B leach rate of $1 \mathrm{~g} / \mathrm{L}$ versus a limit of $16.7 \mathrm{~g} / \mathrm{L}$ ). Limited data was available when the model was developed but much more data is now available, as well as data from Hanford, that could be used to reduce prediction uncertainty and improve model prediction.

- Reexamining radionuclide reporting requirements and associated strategies. As an example, the WAPS requirement is to report the inventory of all radionuclides that have halve lives greater than 10 years and that are, or will be, present in contributions greater than $0.05 \%$ of the total radionuclide inventory indexed to the years 2015 and 3115. This requires extensive measurement of many species that may or may not be of importance for disposal. It also brings in many radionuclides of concern in the out years due to the $0.05 \%$ contribution that were not of concern in the short-term because the other radionuclides have now decayed. The other concern with these criteria is the focus of indexing to 2015 when much of the HLW glass will be produced after this time. The WAPS radionuclide requirements need to be reviewed to determine the data that is ultimately relevant for disposal.

- Reassessing the overall approach to "real waste" qualification and the testing to be performed. Qualification of HLW sludge has shown that some aspects of the radioactive qualification program are more important than others (e.g. learning 
information on the physical properties of the radioactive sample), while other aspects can more easily be defined with simulants (e.g. flowsheet parameters within a predefined process) particularly when assessing the applicability to plant conditions.

- Evaluating the elimination of the pour stream characterization based on successful demonstration of the waste compliance strategy over many batches since start-up. [21] Some of the primary reasons for DWPF taking and characterizing glass pour stream samples during production were to verify the durability model prediction and to confirm that all of the reportable constituents have been identified from sludge and salt characterization. Both of these have been shown to be under control for the DWPF process and should be eliminated. For Hanford, the characterization of pour stream samples is currently not envisioned for radioactive operations but the lesson learned for this particular item is to set the technical basis and strategy for any future elimination of qualification steps that are initially put in place to confirm functionality of the treatment and vitrification system. 


\subsection{Bibliography}

\section{$9.1 \quad$ General}

1. S.L. Marra and M.J. Plodinec. "The DWPF Waste Qualification Program." Proceedings Spectrum 94, Nuclear and Hazardous Waste Management International Topical Meeting. American Nuclear Society. La Grange Park, Il, 1496-1501. 1994.

2. Summary of DWPF Strategies for Compliance with International Atomic Energy Agency (IAEA) Requirements. WSRC-RP-96-40. Revision 0. Savannah River Site, Aiken, SC. January 1996.

3. M.R. Duignan. Final Report Full-Scale Test of DWPF Advanced Liquid-Level and Density Measurement Bubblers. WSRC-RP-97-0103. Savannah River Site, Aiken, SC. April 1997.

4. S.L. Marra, J.T. Gee, and J.F. Sproull. The Defense Waste Processing Facility: Two Years of Radioactive Operation. WSRC-MS-98-00315. Savannah River Site, Aiken, SC. 1998.

5. D.C. Koopman. Comparison of Dow Corning 544 Antifoam to IIT747 Antifoam in the 1/240 SRAT. WSRC-TR-99-00377. Savannah River Site, Aiken, SC. February 2000.

6. C.T. Randall, L.M. Papouchado, and S.L. Marra. "The Defense Waste Processing Facility, from Vision to Reality.” WSRC-MS-2000-00111. Proceedings of the Symposium - 50 Years of Excellence in Science and Engineering at the Savannah River Site, 213-219. 2000.

7. M.R. Norton, H.B. Shah, M.E. Stone, L.E. Johnson, and R.O’Driscoll. Overview - Defense Waste Processing Facility Operating Experience. WSRC-MS-2002-00145. Savannah River Site, Aiken, SC. 2002

8. K. McDaniel. Lessons Learned On SRS DWPF Ventilation Systems and Startup (John J. Barbour Presenter). Bechtel Waste Treatment and Immobilization Project. CCN 036772. October 2002.

9. M.E. Smith, et al. DWPF Melter Glass Pump Implementation and Design Improvement. WSRC-MS-2004-00676. Savannah River Site, Aiken, SC. 2004.

10. M.E. Stone and A.R. Marinik. Small-Scale Mixing Tests for the DWPF Chemical Process Cell Vessels. WSRC-TR-2004-00074. Savannah River Site, Aiken, SC. February 2004.

11. T B. Edwards, D.K. Peeler, and S.L. Marra. Revisiting the Prediction Limits For Acceptable Durability. WSRC-TR-2003-00510. Savannah River Site, Aiken, SC. March 2004.

12. T B. Edwards. Targeting and Estimating Waste Loadings at DWPF: A Sensitivity Analysis. WSRC-TR-2004-00508. Savannah River Site, Aiken, SC. September 2004.

13. F.R. Kaanapu. Lessons Learned - Waste Vitrification Systems. Bechtel Waste Treatment and Immobilization Project. CCN 112658. February 2005. (Includes copy of Waste Vitrification Systems Lessons Learned. U.S. Department of Energy. March 1999) 
14. T.B. Edwards, K.G. Brown, and R.L. Postles. SME Acceptability Determination for DWPF Process Control. WSRC-TR-95-00364. Revision 5. Savannah River Site, Aiken, SC. September 2006.

15. J.M. Bricker, R.T. McNew. Summary of Initiatives to Decrease SRAT Cycle Time and Increase DWPF Throughput. LWO-WSE-2009-00013. Savannah River Site, Aiken, SC. January 2009.

16. C.C. Herman, J.E. Occhipinti, J.F. Iaukea, and A.V. Staub. Overview of SRS Immobilization Process Issues, R\&D, and Future Issues. SRNL-MS-2009-00106. DOE Office of Waste Processing Technical Exchange. May 2009.

17. A.R. Shafer and J.W. Ray. Sludge Batch Checklist. X-ESR-S-00040. Revision 1. Savannah River Site, Aiken, SC. April 2011.

18. T.B. Ryan. Closure Information for DNFSB Request WTP-11-048-01 (DWPF Cesium Data) (CCN 239027). Bechtel Waste Treatment and Immobilization Project. CCN 239027. October 2011.

19. J.R. Zamecnik and D.C.Koopman. Behavior of Mercury During DWPF Chemical Process Cell Processing. SRNL-STI-2012-00051. Savannah River National Laboratory, Aiken, SC. January 2012.

20. D.K. Peeler, E.K. Hansen, C.C. Herman, S.L. Marra, and W.R. Wilmarth. SRNL Phase 1 Assessment of the WTP Waste Qualification Program. SRNL-STI-2011-00723. Savannah River National Laboratory, Aiken, SC. March 2012

21. J.W. Amoroso, D.K. Peeler, and T.B. Edwards. Elimination of the Characterization of DWPF Pour Stream Sample and the Glass Fabrication and Testing of the DWPF Sludge Batch Qualification Sample. SRNL-STI-2012-00157. Savannah River National Laboratory, Aiken, SC. May 2012.

22. E. Harrison, et.al. Waste Acceptance Criteria for Liquid Waste Transfers to the 241-F/H Tank Farms. X-SD-G-00001. Revision 32. Savannah River Site, Aiken, SC. June 2012.

23. C.C. Herman, et al. Preliminary Assessment of the Hanford Tank Waste Feed Acceptance and Product Qualification Programs. SRNL-STI-2012-00776 and PNNL-22116. Revision 0. March 2013.

24. J.W. Ray. Waste Acceptance Criteria for Sludge, ARP, and MCU Process Transfers to 512-S and DWPF. X-SD-G-00008. Revision 11. Savannah River Site, Aiken, SC. May 2013.

25. DWPF Waste Acceptance Reference Manual. WSRC-IM-93-40. Revision 25. Savannah River Site, Aiken, SC. June 2013.

9.2 SRS - Hanford Waste Feed Qualification Meeting May 72013

26. SRS-Hanford Waste Feed Qualification Integration Meeting - Summary Notes. SRR-STI2013-00344.

27. S.L. Marra and H. Elder. DWPF Waste Qualification/Feed Acceptance Activities: Road to Sludge Batch 1. 
SRNL-STI-2013-00585

Revision 0

28. J.W. Ray. DWPF Waste Acceptance Criteria Related to Sludge Batch Qualification. SRRSTI-2013-00273.

29. C.C. Herman. Sampling and Analysis for DWPF Feed Qualification.

30. D. Bumgardner and H. Shah. Sludge Batch Planning, Tank Mixing and Sampling.

9.3 WM Symposia, Annual Waste Management Conference, Papers (Downloaded from http://www.wmsym.org/index.php/archives/online-proceedings, June 2013.)

31. WM1995-35-01.R.E. Erkison, et. al. "Vitrification Facility High Level Waste Acceptance Strategies.” Proceedings - Waste Management 1995, Session 35-01.

32. WM1996-08-02. S.L. Marra, D.E. Snyder, H.H. Elder and J.E. Occhipinti, "The DWPF: Results of Full Scale Qualification Runs Leading to Radioactive Operations." Proceedings - Waste Management 1996, Session 8-2. WSRC-MS-95-0488.

33. WM1997-14-01. S.P. Cowan, et al. "High-Level Waste Vitrification - A Reality." Proceedings - Waste Management 1997, Session 14-01.

34. WM1997-14-05. D.B. Little, J.T. Gee, W.M. Barnes, "Defense Waste Processing Facility, Radioactive Operations - Part I - Operating Experience.” Proceedings - Waste Management 1997, Session 14-05. WSRC-MS-97-0080.

35. WM1997-14-06. J.T. Carter, K.J. Rueter, J.W. Ray and O. Hodoh. "Defense Waste Processing Facility Radioactive Operations - Part II Glass Making.” Proceedings - Waste Management 1997, Session 14-06. WSRC-MS-96- 0798.

36. WM1997-14-07. W D. Kerley, W.M. Barnes, and P.D. Hughes, "Defense Waste Processing Facility Radioactive Operations -Part III - Remote Operations." Proceedings - Waste Management 1997, Session 14-07.

37. WM1998-14-01. T.J. Rowland, G.P. Rudy, and J.D. Wagoner. "Vitrification: A Success Story in 1997 Across The DOE Complex.” Proceedings - Waste Management 1998, Session 14-01.

38. WM1998-14-02. W.F. Hamel, Jr., P J. Valenti, and D.I. Elliott. "Lessons Learned From The First Year of Radioactive Operations of The West Valley Demonstration Project Vitrification System.” Proceedings - Waste Management 1998, Session 14-02.

39. WM1998-14-03. J.T. Carter, R.E. Edwards, J E. Occhipinti, R.S. Beck and D.C. Iverson. “Defense Waste Processing Facility Radioactive Operations - Year Two.” Proceedings Waste Management 1998, Session 14-03.

40. WM2008-8366. R.J. O’Driscoll, A.B. Barnes, J.R. Coleman, T L. Glover, R.C. Hopkins, D.C. Iverson, and J.N. Leita. "Recent Process and Equipment Improvements to Increase High Level Waste Throughput at The Defense Waste Processing Facility (DWPF).” Proceedings - Waste Management 2008, 8366. (WSRC-MS-2007-00177). 
41. WM2013-13598. J.W. Ray, S.L. Marra, and C.C. Herman. "Reevaluation of Vitrified HighLevel Waste Form Criteria for Potential Cost Savings at the Defense Waste Processing Facility.” Proceedings - Waste Management 2013, 13598.

\subsection{EM-WAPS}

42. Office of Environmental Restoration and Waste Management. Waste Acceptance Product Specifications for Vitrified High-Level Waste Forms. Revision 2. U.S. DOE Document EM-WAPS. U.S. Department of Energy, Germantown, MD (1996).

43. Office of Environmental Management. Waste Acceptance Product Specifications for Vitrified High Level-Waste Forms. DOE/EM-0093. Revision 3. US Department of Energy, Washington, DC (2012).

9.5 Office of Civilian Radioactive Waste Management

44. Office of Civilian Radioactive Waste Management. Waste Acceptance System Requirements Document. DOE/RW-0351. Revision 5, ICN 01. US Department of Energy, Washington, DC (2008).

45. Office of Civilian Radioactive Waste Management. Integrated Interface Control Document. DOE/RW-0511. Volume 1. Revision 4, ICN 1. US Department of Energy, Washington, DC (2008).

46. Office of Civilian Radioactive Waste Management. Quality Assurance Requirements and Description. DOE/RW-0333P. Revision 21. (2008).

9.6 DWPF Waste Form Compliance Plan (WCP)

47. WCP-0. DWPF Waste Form Compliance Plan. WSRC-IM-91-116-0, Revision 9. Savannah River Site, Aiken, SC. June 2012.

9.7 DWPF Waste Form Qualification Report (WQR) (WSRC-IM-91-116-X)

48. WQR-1. J.R. Fowler, R.E. Edwards, S.L. Marra and M.J. Plodinec. Chemical Composition Projections for the DWPF Product. WSRC-IM-91-116-1. Revision 1. Savannah River Site, Aiken, SC. November 1995.

49. WQR-2. J.W. Ray, A.V. Staub, S.L. Marra, C.J. Coleman and M.J. Plodinec. Reporting The Chemical Composition of the DWPF Product. WSRC-IM-91-116-2. Revision 5. Savannah River Site, Aiken, SC. June 2012.

50. WQR-3. M.J. Plodinec and S.L. Marra. Projected Radionuclide Inventories and Radiogenic Properties of the DWPF Product. WSRC-IM-91-116-3. Revision 0. Savannah River Site, Aiken, SC. October 1994.

51. WQR-4. A.V. Staub, J.W. Ray, T.B. Edwards, N.E. Bibler, and S.L. Marra. Reporting the Radionuclide Inventory of the DWPF Product. WSRC-IM-91-116-4. Revision 3. Savannah River Site, Aiken, SC. March 2006.

52. WQR-5. J.W. Ray, B.H. Culbertson, S.L. Marra, C. M. Jantzen, and T.B. Edwards. Technical Bases for the DWPF Product Control Program. WSRC-IM-91-116-5. Revision 3. Savannah River Site, Aiken, SC. March 2006. 
53. WQR-6. J.W. Ray, B.H. Culbertson, S.L. Marra and M.J. Plodinec. DWPF Glass Product Control Program. WSRC-IM-91-116-6. Revision 7. Savannah River Site, Aiken, SC. June 2012.

54. WQR-7. B.H. Culbertson, S.L. Marra, M.K. Andrews, C.A. Cicero, B.J. Hardy, and M.J. Plodinec. Phase Stability and Control of the Temperature of the DWPF Product. WSRCIM-91-116-7. Revision 1. Savannah River Site, Aiken, SC. March 2006.

55. WQR-8. B.H. Culbertson, J.W. Ray, S.L. Marra, J.R. Harbour, and M.J. Plodinec. DWPF Canister Procurement, Control, Drop Test, and Closure. WSRC-IM-91-116-8. Revision 3. Savannah River Site, Aiken, SC. March 2006.

56. WQR-9. A.V. Staub, J.W. Ray, J.R. Harbour, S.L. Marra, and M.J. Plodinec. Exclusion of Foreign Materials and Prevention of Internal Corrosion of DWPF Canistered Waste Forms. WSRC-IM-91-116-9. Revision 3. Savannah River Site, Aiken, SC. March 2006.

57. WQR-10. S.L. Marra and M.J. Plodinec. Controlling the Glass Fill Height of the DWPF Product. WSRC-IM-91-116-10. Revision 0. Savannah River Site, Aiken, SC. November 1995.

58. WQR-11. B.H. Culbertson, J.W. Ray, S.L. Marra, and M.J. Plodinec. Control of Surface Contamination. WSRC-IM-91-116-11. Revision 3. Savannah River Site, Aiken, SC. March 2006.

59. WQR-12. B.H. Culbertson, M.J. Plodinec, F.S. Moore, and S.L. Marra. Reporting Dose and Heat Generation Rates of the DWPF Product. WSRC-IM-91-116-12. Revision 1. Savannah River Site, Aiken, SC. March 2006.

60. WQR-13. A. Applewhite-Ramsey, S.L. Marra and M.J. Plodinec. Hazardous Waste Determination of the DWPF Product. WSRC-IM-91-116-13. Revision 0. Savannah River Site, Aiken, SC. February 1995. 
SRNL-STI-2013-00585

Revision 0

Appendix A. EM-WAPS Crosswalk to WCP/WQR (WSRC-IM-91-116-X) 
Table BAppendix A, EM-WAPS Crosswalk to WCP/WQR (WSRC-IM-91-116-X)

This appendix includes a crosswalk between the EM-WAPS and the DWPF WCP and WQR Volumes.

Table A-1. EM-WAPS Crosswalk to WCP/WQR (WSRC-IM-91-116-X)

\begin{tabular}{|c|c|c|}
\hline EM-WAPS Sections & WSRC-IM-91-116-X & WCP Part or WQR Volume \\
\hline \multicolumn{3}{|l|}{ 1.0 WASTE FORM SPECIFICATIONS } \\
\hline \multicolumn{3}{|l|}{ 1.1 CHEMICAL SPECIFICATION } \\
\hline 1.1.1 Chemical Composition Projections & $\begin{array}{l}0 \\
1 \\
\end{array}$ & $\begin{array}{l}\text { WCP Part 3, Item } 100 \\
\text { Chemical Composition Projections for the DWPF Product }\end{array}$ \\
\hline 1.1.2 Chemical Composition During Production & $\begin{array}{l}0 \\
2\end{array}$ & $\begin{array}{l}\text { WCP Part 3, Item } 200 \\
\text { Reporting the Chemical Composition of the DWPF Product }\end{array}$ \\
\hline \multicolumn{3}{|l|}{ 1.2 RADIONUCLIDE INVENTORY SPECIFICATION } \\
\hline 1.2.1 Radionuclide Inventory Projection & $\begin{array}{l}0 \\
3\end{array}$ & $\begin{array}{l}\text { WCP Part 3, Item } 300 \\
\text { Projected Radionuclide Inventories and Radiogenic Properties } \\
\text { of the DWPF Product }\end{array}$ \\
\hline 1.2.2 Radionuclide Inventory During Production & $\begin{array}{l}0 \\
4\end{array}$ & $\begin{array}{l}\text { WCP Part 3, Item } 400 \\
\text { Radionuclide Inventory during Production }\end{array}$ \\
\hline $\begin{array}{l}\text { 1.3 SPECIFICATION FOR PRODUCT CONSISTENCY } \\
\text { 1.3.1 Acceptance Criterion } \\
\text { 1.3.2 Method of Compliance }\end{array}$ & $\begin{array}{l}0 \\
5 \\
6\end{array}$ & $\begin{array}{l}\text { WCP Part 3, Item } 500 \\
\text { Technical Bases for the DWPF Glass Product Control Program } \\
\text { DWPF Glass Product Control Program }\end{array}$ \\
\hline $\begin{array}{l}\text { 1.4 SPECIFICATION FOR PHASE STABILITY } \\
\text { 1.4.1 Phase Stability Information } \\
\text { 1.4.2 Control of Temperature for Phase Stability }\end{array}$ & $\begin{array}{l}0 \\
7\end{array}$ & $\begin{array}{l}\text { WCP Part 3, Item } 600 \\
\text { Phase Stability and Control of the Temperature of the DWPF } \\
\text { Product }\end{array}$ \\
\hline 1.5 HAZARDOUS WASTE SPECIFICATION & $\begin{array}{l}0 \\
13 \\
\end{array}$ & $\begin{array}{l}\text { WCP Part 3, Item } 500 \\
\text { Hazardous Waste Determination of the DWPF Product }\end{array}$ \\
\hline 1.6 IAEA SAFEGUARDS REPORTING FOR HLW & $\begin{array}{l}0 \\
6\end{array}$ & $\begin{array}{l}\text { WCP Part 3, Item } 800 \\
\text { DWPF Glass Product Control Program } \\
\text { WSRC-RP-96-40 }\end{array}$ \\
\hline \multicolumn{3}{|l|}{ 2.0 CANISTER SPECIFICATIONS } \\
\hline 2.1 MATERIAL SPECIFICATION & $\begin{array}{l}0 \\
8\end{array}$ & $\begin{array}{l}\text { WCP Part 4, Item } 100 \\
\text { Canister Procurement, Control, Drop Test and Closure }\end{array}$ \\
\hline 2.2 FABRICATION AND CLOSURE SPECIFICATION & $\begin{array}{l}0 \\
8\end{array}$ & $\begin{array}{l}\text { WCP Part 4, Item } 200 \\
\text { Canister Procurement, Control, Drop Test and Closure }\end{array}$ \\
\hline $\begin{array}{l}\text { 2.3 IDENTIFICATION AND LABELING SPECIFICATION } \\
\text { 2.3.1 Identification } \\
\text { 2.3.2 Labeling }\end{array}$ & $\begin{array}{l}0 \\
8\end{array}$ & $\begin{array}{l}\text { WCP Part 4, Item } 300 \\
\text { Canister Procurement, Control, Drop Test and Closure }\end{array}$ \\
\hline
\end{tabular}




\begin{tabular}{|c|c|c|}
\hline EM-WAPS Sections & WSRC-IM-91-116-X & WCP Part or WQR Volume \\
\hline $\begin{array}{l}\text { 2.4 SPECIFICATION FOR CANISTER LENGTH AND } \\
\text { DIAMETER } \\
\text { 2.4.1 Length Specification } \\
\text { 2.4.2 Diameter Specification }\end{array}$ & $\begin{array}{l}0 \\
8\end{array}$ & $\begin{array}{l}\text { WCP Part 4, Item } 400 \\
\text { Canister Procurement, Control, Drop Test and Closure }\end{array}$ \\
\hline \multicolumn{3}{|l|}{ 3.0 CANISTERED WASTE FORM SPECIFICATIONS } \\
\hline 3.1 FREE LIQUID SPECIFICATION & $\begin{array}{l}0 \\
9\end{array}$ & $\begin{array}{l}\text { WCP Part 5, Item } 100 \\
\text { Exclusion of Foreign Materials and Prevention of Internal } \\
\text { Corrosion of DWPF Canistered Waste Forms }\end{array}$ \\
\hline $\begin{array}{l}\text { 3.2 TAMPER INDICATING SEALS FOR HIGH-LEVEL } \\
\text { WASTE CANISTERS }\end{array}$ & $\begin{array}{l}0 \\
9\end{array}$ & $\begin{array}{l}\text { WCP Part 5, Item } 150 \\
\text { Exclusion of Foreign Materials and Prevention of Internal } \\
\text { Corrosion of DWPF Canistered Waste Forms }\end{array}$ \\
\hline $\begin{array}{l}\text { 3.3 SPECIFICATION FOR EXPLOSIVENESS, } \\
\text { PYROPHORICITY, AND COMBUSTIBILITY }\end{array}$ & $\begin{array}{l}0 \\
9\end{array}$ & $\begin{array}{l}\text { WCP Part 5, Item } 200 \\
\text { Exclusion of Foreign Materials and Prevention of Internal } \\
\text { Corrosion of DWPF Canistered Waste Forms }\end{array}$ \\
\hline 3.4 ORGANIC MATERIALS SPECIFICATION & $\begin{array}{l}0 \\
9\end{array}$ & $\begin{array}{l}\text { WCP Part 5, Item } 250 \\
\text { Exclusion of Foreign Materials and Prevention of Internal } \\
\text { Corrosion of DWPF Canistered Waste Forms }\end{array}$ \\
\hline 3.5 CHEMICAL COMPATIBILITY SPECIFICATION & $\begin{array}{l}0 \\
9\end{array}$ & $\begin{array}{l}\text { WCP Part 5, Item } 300 \\
\text { Exclusion of Foreign Materials and Prevention of Internal } \\
\text { Corrosion of DWPF Canistered Waste Forms }\end{array}$ \\
\hline $\begin{array}{l}\text { 3.6 HIGH LEVEL CANISTERED WASTE FORM METRIC } \\
\text { TONS OF HEAVY METAL CONTENT }\end{array}$ & $\begin{array}{l}0 \\
10\end{array}$ & $\begin{array}{l}\text { WCP Part 5, Item } 350 \\
\text { Controlling the Glass Fill Height of the DWPF Product }\end{array}$ \\
\hline $\begin{array}{l}\text { 3.7 SPECIFICATION FOR REMOVABLE RADIOACTIVE } \\
\text { CONTAMINATION ON EXTERNAL SURFACES }\end{array}$ & $\begin{array}{l}0 \\
11\end{array}$ & $\begin{array}{l}\text { WCP Part 5, Item } 400 \\
\text { Control of Surface Contamination }\end{array}$ \\
\hline \multicolumn{3}{|l|}{ 3.8 HEAT GENERATION SPECIFICATION } \\
\hline 3.8.1 Heat Generation Projections & $\begin{array}{l}0 \\
3\end{array}$ & $\begin{array}{l}\text { WCP Part 5, Item } 450 \\
\text { Projected Radionuclide Inventories and Radiogenic Properties } \\
\text { of the DWPF Product }\end{array}$ \\
\hline 3.8.2 Heat Generation at Year of Shipment & $\begin{array}{l}0 \\
12\end{array}$ & $\begin{array}{l}\text { WCP Part 5, Item } 500 \\
\text { Reporting Dose and Heat Generation Rates of the DWPF } \\
\text { Product }\end{array}$ \\
\hline \multicolumn{3}{|l|}{ 3.9 SPECIFICATION FOR MAXIMUM DOSE RATES } \\
\hline 3.9.1 Projections of Dose Rates & $\begin{array}{l}0 \\
3\end{array}$ & $\begin{array}{l}\text { WCP Part 5, Item } 550 \\
\text { Projected Radionuclide Inventories and Radiogenic Properties } \\
\text { of the DWPF Product }\end{array}$ \\
\hline 3.9.2 Dose Rates at Time of Shipment & $\begin{array}{l}0 \\
12\end{array}$ & $\begin{array}{l}\text { WCP Part 5, Item } 600 \\
\text { Reporting Dose and Heat Generation Rates of the DWPF } \\
\text { Product }\end{array}$ \\
\hline
\end{tabular}




\begin{tabular}{|c|c|c|}
\hline EM-WAPS Sections & WSRC-IM-91-116-X & WCP Part or WQR Volume \\
\hline $\begin{array}{l}\text { 3.10 SUBCRITICALITY SPECIFICATION } \\
\text { 3.10.1 Pre-Closure Criticality } \\
\text { 3.10.2 Post-Closure Criticality }\end{array}$ & $\begin{array}{l}0 \\
3\end{array}$ & $\begin{array}{l}\text { WCP Part 5, Item } 650 \\
\text { Projected Radionuclide Inventories and Radiogenic Properties } \\
\text { of the DWPF Product }\end{array}$ \\
\hline $\begin{array}{l}\text { 3.11 SPECIFICATIONS FOR WEIGHT AND OVERALL } \\
\text { DIMENSIONS } \\
\text { 3.11.1 Weight Specification } \\
\text { 3.11.2 Specification for Overall Dimensions }\end{array}$ & $\begin{array}{l}0 \\
8\end{array}$ & $\begin{array}{l}\text { WCP Part 5, Item } 700 \\
\text { Canister Procurement, Control, Drop Test and Closure }\end{array}$ \\
\hline 3.12 DROP TEST SPECIFICATION & $\begin{array}{l}0 \\
8\end{array}$ & $\begin{array}{l}\text { WCP Part 5, Item } 750 \\
\text { Canister Procurement, Control, Drop Test and Closure }\end{array}$ \\
\hline 3.13 HANDLING FEATURES SPECIFICATION & $\begin{array}{l}0 \\
8\end{array}$ & $\begin{array}{l}\text { WCP Part 5, Item } 800 \\
\text { Canister Procurement, Control, Drop Test and Closure }\end{array}$ \\
\hline $\begin{array}{l}\text { 3.14 CONCENTRATION OF PLUTONIUM IN EACH } \\
\text { CANISTER SPECIFICATION }\end{array}$ & & WSRC-RP-96-40 \\
\hline 4.0 QUALITY ASSURANCE SPECIFICATION & 0 & WCP Part 6, Item 100 and 300, \\
\hline \multicolumn{3}{|l|}{ 4.1 QUALITY ASSURANCE } \\
\hline 4.2 NON-CONFORMANCES & & $\begin{array}{l}\text { SRS Quality Assurance Manual , 1Q, Procedure QAP 15-1, } \\
\text { Control of Nonconforming Items }\end{array}$ \\
\hline \multicolumn{3}{|l|}{ 5.0 DOCUMENTATION AND OTHER REQUIREMENTS } \\
\hline \multicolumn{3}{|l|}{$\begin{array}{l}\text { 5.1 SPECIFICATION FOR WASTE ACCEPTANCE } \\
\text { DOCUMENTATION }\end{array}$} \\
\hline 5.1.1 Waste Form Compliance Plan (WCP) & 0 & WCP all \\
\hline 5.1.2 Waste Form Qualification Report (WQR) & $1-13$ & WQR volumes 1 - 13 \\
\hline \multicolumn{3}{|l|}{ 5.1.3 Production Records (PR) } \\
\hline \multicolumn{3}{|l|}{ 5.1.4 Storage and Shipping Records } \\
\hline \multicolumn{3}{|l|}{$\begin{array}{l}\text { 5.2 SPECIFICATION FOR HIGH-LEVEL WASTE } \\
\text { TRANSACTION REPORTING }\end{array}$} \\
\hline \multicolumn{3}{|l|}{$\begin{array}{l}\text { 5.3 SPECIFICATION FOR DELIVERY OF } \\
\text { NONCONFORMING WASTE FORMS }\end{array}$} \\
\hline \multicolumn{3}{|l|}{ 5.4 SPECIFICATION FOR TRANSFER OF HLW TO RW } \\
\hline \multicolumn{3}{|l|}{ 5.5 SPECIFICATION FOR HLW ANNUAL REPORT } \\
\hline 5.6 HLW RECEIPT & & \\
\hline
\end{tabular}


SRNL-STI-2013-00585

Revision 0

Appendix B. DWPF Waste Acceptance Criteria 


\section{Appendix B, DWPF Waste Acceptance Criteria}

This appendix provides a summary of the DWPF WAC in X-SD-G-00008. [24] The table includes a column listing the source for the WAC limit or target. In many cases the limit or target is more conservative than the value in the GPCP. The sections of the DWPF WAC document include a description of the criteria, the criteria type, and the computational technique.

Table B-1. DWPF Waste Acceptance Criteria

\begin{tabular}{|c|c|c|c|c|}
\hline $\begin{array}{c}\text { WAC } \\
\text { Section }\end{array}$ & Topic & Criteria & $\begin{array}{c}\text { Criteria } \\
\text { Type }\end{array}$ & Related to \\
\hline 5.4 .1 & NOx Emissions & $<103.52$ tons/year & Target & $\begin{array}{c}\text { Environmental } \\
\text { Emissions }\end{array}$ \\
\hline 5.4 .3 & Gamma Shielding & $\begin{array}{l}\text { a. Sludge: }<4070 \mathrm{mR} / \mathrm{hr} / \text { gallon and } 3.7 \mathrm{mR} / \mathrm{hr} / \text { gram insoluble solids } \\
\text { b. } \quad \text { MCU: }<16.5 \mathrm{Ci} / \text { gallon } \mathrm{Cs}-137\end{array}$ & Limit & Personnel Protection \\
\hline 5.4 .4 & Neutron Shielding & Total alpha $<1.5 \mathrm{E}-03 \mathrm{Ci} /$ gram insoluble solids & Limit & Personnel Protection \\
\hline 5.4 .5 & $\begin{array}{l}\text { Inhalation Dose } \\
\text { Potential }\end{array}$ & $\begin{array}{ll}\text { a. } & \text { Sludge } \leq 2.47 \mathrm{E}+08 \mathrm{rem} / \text { gallon } \\
\text { b. } & \text { Sludge Cs }-137 \leq 1.34 \mathrm{Ci} / \text { gallon } \\
\text { c. } & \text { MCU Cs }-137 \leq 16.5 \mathrm{Ci} / \text { gallon }\end{array}$ & Limit & $\begin{array}{l}\text { Safety Basis } \\
\text { Assumption }\end{array}$ \\
\hline 5.4 .6 & $\begin{array}{l}\text { Nuclear Criticality } \\
\text { Safety }\end{array}$ & $\begin{array}{ll}\text { a. } & \mathrm{Pu}-240 \geq \mathrm{Pu}-241 \\
\text { b. } & \text { Fe to } \mathrm{Pu}-239(\mathrm{eq}) \geq 160: 1 \text { (sludge from Tank Farm only) } \\
\text { c. } & \text { The } \mathrm{Pu}-239(\mathrm{eq}) \leq 0.59 \mathrm{~g} / \text { gallon only if non-Tank Farm } \mathrm{Pu} \\
\text { d. } & \mathrm{U}-235(\mathrm{eq}) \text { sludge } \leq 0.93 \mathrm{wt} . \%\end{array}$ & Limit & $\begin{array}{l}\text { Safety Basis } \\
\text { Assumption }\end{array}$ \\
\hline 5.4 .7 & Glass Solubility & $\begin{array}{l}\mathrm{TiO}_{2} \leq 2.00, \mathrm{Cr}_{2} \mathrm{O}_{3} \leq 0.30, \mathrm{Cu} \leq 0.50, \mathrm{PO}_{4} \leq 3.00, \mathrm{NaF} \leq 1.00, \mathrm{NaCl} \leq 1.00 \text {, and } \\
\mathrm{SO}_{4}\left(\mathrm{Na}_{2} \mathrm{SO}_{4}\right) \leq 0.60(0.88) \text { (criteria are based on wt } \% \text { in glass) }\end{array}$ & Limit & $\begin{array}{l}\text { Repository } \\
\text { Requirements/Safety } \\
\text { Basis Assumptions }\end{array}$ \\
\hline 5.4 .8 & Corrosive Species & $\begin{array}{l}\text { a. } \text { Sludge Slurry - Sulfate }<0.058 \mathrm{M} \\
\text { b. } \quad \text { Sludge Slurry } \mathrm{Hg}<21 \mathrm{~g} / 1 \text { slurry }\end{array}$ & Limit & $\begin{array}{l}\text { Materials Test } \\
\text { Program }\end{array}$ \\
\hline 5.4 .9 & $\begin{array}{l}\text { Sludge Solids } \\
\text { Contents }\end{array}$ & Sludge Slurry Range: 12 - 19 wt\% dry total solids & Target & $\begin{array}{l}\text { Sludge Receipt from } \\
\text { H-Tank Farm }\end{array}$ \\
\hline 5.4 .10 & $\begin{array}{l}\text { Glass Quality and } \\
\text { Processability }\end{array}$ & $\begin{array}{l}\text { a. } \text { B Leach Rate } \leq 16.70 \mathrm{~g} / \mathrm{l} \text {, Li Leach Rate } \leq 9.57 \mathrm{~g} / \mathrm{l} \text {, and } \mathrm{Na} \text { Leach Rate } \leq \\
13.35 \mathrm{~g} / 1 \\
\text { b. Liquidus Temperature }-\leq 1050^{\circ} \mathrm{C} \\
\text { c. High Viscosity - } \leq 110 \text { poise, Low Viscosity } \geq 20 \text { poise } \\
\text { d. Homogeneity (Alumina/Alkali) Constraint- } \mathrm{Al}_{2} \mathrm{O}_{3} \geq 4 \mathrm{wt} \% \text { OR } \mathrm{Al}_{2} \mathrm{O}_{3} \geq 3 \\
\text { wt\% AND } \sum \mathrm{M}_{2} \mathrm{O}<19.3 \text { wt } \% \text { where } \sum \mathrm{M}_{2} \mathrm{O}=\mathrm{Na}_{2} \mathrm{O}+\mathrm{Li}_{2} \mathrm{O}+\mathrm{Cs}_{2} \mathrm{O}+\mathrm{K}_{2} \mathrm{O} \\
\text { wt\% } \\
\text { e. Nepheline- }>0.62 \text { where Nepheline }=\mathrm{SiO}_{2} /\left(\mathrm{SiO}_{2}+\mathrm{Na}_{2} \mathrm{O}+\mathrm{Al}_{2} \mathrm{O}_{3}\right)\end{array}$ & Limits & $\begin{array}{l}\text { Repository } \\
\text { Requirements }\end{array}$ \\
\hline
\end{tabular}


SRNL-STI-2013-00585

Revision 0

\begin{tabular}{|c|c|c|c|c|}
\hline $\begin{array}{c}\text { WAC } \\
\text { Section }\end{array}$ & Topic & Criteria & $\begin{array}{c}\text { Criteria } \\
\text { Type }\end{array}$ & Related to \\
\hline 5.4 .11 & $\begin{array}{l}\mathrm{H}_{2} \text { Generation } / \mathrm{N}_{2} \mathrm{O} \\
\text { Concentration }\end{array}$ & $\begin{array}{l}\text { a. SRAT Hydrogen }<0.65 \mathrm{lb} / \mathrm{hr} \text { for } 6000 \text { gallons } \\
\text { b. SRAT } \mathrm{N}_{2} \mathrm{O}<15 \text { vol.\% } \\
\text { c. SME Hydrogen }<0.223 \mathrm{lb} / \mathrm{hr} \text { for } 6000 \text { gallons }\end{array}$ & Limits & $\begin{array}{l}\text { Safety Basis } \\
\text { Assumptions }\end{array}$ \\
\hline 5.4 .12 & $\begin{array}{l}\text { Radiolytic } \mathrm{H}_{2} \\
\text { Generation }\end{array}$ & $\begin{array}{l}\text { a. } \quad<8.95 \mathrm{E}-05 \mathrm{ft} 3 / \mathrm{hr} / \text { gal at } 25^{\circ} \mathrm{C} \\
\text { b. } \quad \text { Extended recovery time: }<1.3313 \mathrm{E}-05 \mathrm{ft} 3 / \mathrm{hr} / \text { gal at } 25^{\circ} \mathrm{C}\end{array}$ & Limit & $\begin{array}{l}\text { Safety Basis } \\
\text { Assumptions }\end{array}$ \\
\hline 5.4 .13 & $\begin{array}{l}\text { Organic Carbon } \\
\text { Concentration }\end{array}$ & $\begin{array}{l}\text { Organic Material in sludge feed shall contribute }<0.1 \% \text { to the hydrogen LFL } \\
\text { (MCU excluded) }\end{array}$ & Limit & $\begin{array}{l}\text { Safety Basis } \\
\text { Assumptions }\end{array}$ \\
\hline 5.4 .14 & $\mathrm{pH}$ & $\begin{array}{l}\text { a. Strip effluent shall have a } \mathrm{pH} \geq 2 \text { and } \leq 4 \text {. } \\
\text { b. A full line volume of water or Strip Effluent flush shall be transferred } \\
\text { through the Transfer Lines within } 2 \text { weeks after Contactor Cleaning } \\
\text { Solution (nominally } 3 \mathrm{M} \mathrm{HNO}_{3} \text { ) is transferred }\end{array}$ & Limit & Corrosion \\
\hline 5.4 .15 & Temperature & $\begin{array}{l}\text { a. Sludge transfers from Tank } 40 \text { shall be } \leq 45^{\circ} \mathrm{C} \\
\text { b. Strip Effluent transfers from } \mathrm{MCU} \text { shall be } \leq 40^{\circ} \mathrm{C}\end{array}$ & Limit & $\begin{array}{l}\text { Safety Basis } \\
\text { Assumptions }\end{array}$ \\
\hline 5.4 .16 & Particle Size & New product streams particle size 80 mesh sieve or equivalent & Limit & $\begin{array}{l}\text { Repository } \\
\text { Requirements }\end{array}$ \\
\hline
\end{tabular}


SRNL-STI-2013-00585

Revision 0

Appendix C. Sludge Batch Preparation and Qualification Flowchart 


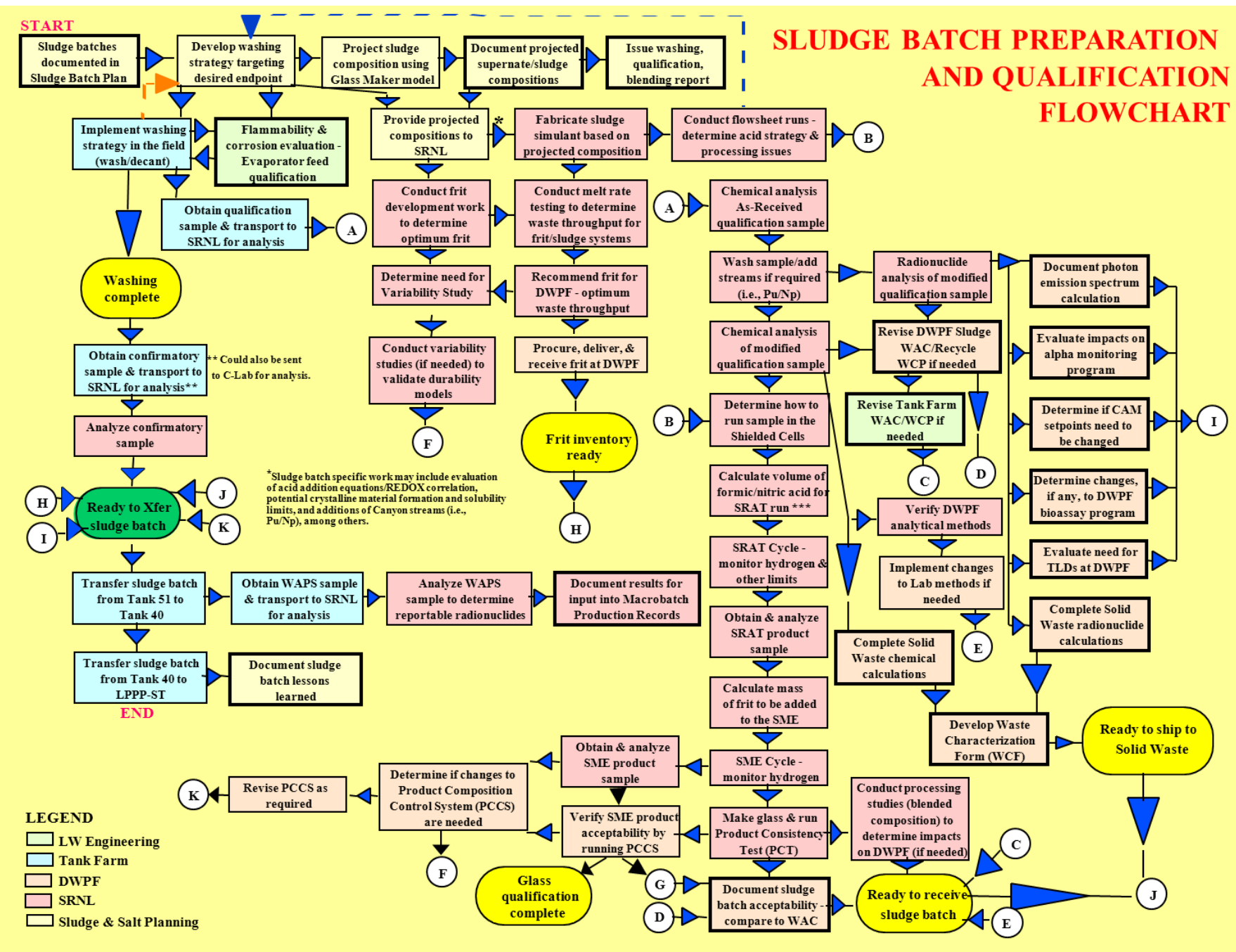

Figure C-1 Sludge Batch Preparation and Qualification Flowchart 


\section{Distribution:}

SRNL:

S. L. Marra, 773-A

T. B. Brown, 773-A

M. J. Cercy, 773-42A

D. R. Click, 999-W

S. D. Fink, 773-A

C. C. Herman, 773-A

E. N. Hoffman, 999-W

F. M. Pennebaker, 773-42A

W. R. Wilmarth, 773-A

M. E. Stone, 999-W

S. H. Reboul, 773-42A

D. K. Peeler, 999-W

J. E. Young, 773-41A

M. Restivo, 773-42A

E. K. Hansen, 999-W

D. J. Adamson, 999-W

Records Administration (EDWS)

SRR:

K. H. Subramanian, 241-156H

J. W. Ray, 704-S

J. M. Bricker, 704-27S

J. Tseng

DOE-SR:

P. R. Jackson, DOE-SR, 703-46A
WTP:

A. V. Arakali

S. M. Barnes

P. A. Benson

G. M. Duncan

M. R. Hamlet

J. Markillie

J. L. Nelson

I. G. Papp

WRPS:

S. T. Arm

T. W. Crawford

W. G. Ramsey

J. G. Reynolds

P. L. Rutland

S. A. Saunders

D. H. Shuford

M. G. Thien

L. E. Thompson

PNNL:

R. D. Peterson

DOE-ORP:

D. H. Alexander

S. L. Charboneau

J. A. Diediker

T. W. Fletcher

B. J. Harp

C. C. Harrington

A. A. Kruger

P. Logan

I. Wheeler

W. R. Wrzesinski 